$$
\text { punto org }
$$

Collana diretta da Luigi Maria Sicca

44 
Francesco Piro Luigi Maria Sicca Pietro Maturi Massimo Seuillante Maura Striano

\title{
SFIDE DIDATTICHE
}

IL PENSIERO CRITICO NELLA SCUOLA

E NELL'UNIVERSITÀ

\author{
prefazione \\ Francesco Sabatini
}

Davide Bizjak - Paolo Canonico - Rosaria Capobianco - Bice Cavallo Stefano Consiglio - Ernesto De Nito - Gerarda Fattoruso Maria Incoronata Fredella - Teresa Anna Rita Gentile - Roberta Gimigliano Chiara Mallozzi - Luca Marano - Luigi Marolda - Pietro Maturi Monica Mollo - Mario Nicodemi - Maria Grazia Olivieri Maria Rita Petitti - Francesco Piro - Luigi Proserpio - Giuseppe Recinto Fabio Maria Risolo - Luigi Maria Sicca - Massimo Squillante Maura Striano - Antonia Travaglione - Natascia Villani

\section{Editoriale Scientifica \\ Napoli}




\section{Indice}

13 Prefazione

di Francesco Sabatini

17 Guida al testo

Francesco Piro, Luigi Maria Sicca, Pietro Maturi, Massimo Squillante, Maura Striano

Sezione I - Didattica e pensiero critico: il potere DELL'ARGOMENTARE

27 1. Il PENSIERO CRITICO E LE COMPETENZE PER L'APPRENDIMENTO PERMANENTE

Maura Striano, Rosaria Capobianco, Maria Rita Petitti

27 1.1. Pensiero critico e comunità di ricerca in Matthew Lipman

32 1.2. La comunità di ricerca come paradigma metodologico per il potenziamento delle competenze sociali e civiche

37 1.3. Quali competenze per l'apprendimento permanente?

40 1.4. Il pensiero critico come abilità trasversale

44 1.5. Imparare ad imparare e pensiero critico: competenze chiave per l'apprendimento

$50 \quad 1.6$. Le nuove sfide per la scuola delle competenze

55 1.7. Dalla progettazione a ritroso all'Unità di Apprendimento (UdA o UA)

65 1.8. Imparare ad imparare e pensiero critico: un'ipotesi di Unità di Apprendimento

83 2. C'È LOGICA NEL PENSIERO CRITICO?

Francesco Piro 
97 3. COMPETENZE E PENSIERO CRITICO NELL'INSEGNAMENTO LICEALE: UNA SPERIMENTAZIONE

Roberta Gimigliano

97 3.1. Introduzione

101

106

3.2. Imparare a concettualizzare

107

109

3.3. Imparare a ragionare

3.3.1. Il ragionamento deduttivo

3.3.2. Il ragionamento induttivo

3.3.3. Il ragionamento abduttivo

3.4. Imparare ad argomentare

3.5. Imparare a giudicare

3.5.1. Introduzione

3.5.2. Il testo

3.5.3. Il saggio breve

4. IL POTERE INTRINSECO DELL'ARGOMENTAZIONE NEI PROCESSI DI APPRENDIMENTO

Monica Mollo

4.1. Introduzione

4.2. Argomentazione come dialogo

4.3. Il contesto argomentativo

4.4. Attività didattica

4.4.1. Organizzazione del corso

4.4.2. Partecipanti e metodologia

4.4.3. Analisi delle argomentazioni

4.5. Considerazioni finali

Sezione II - Didattica e PENSiero CRItico: linguaggi, VARIAZIONI, DECISIONI

143 5. LE DECISIONI. UN PERCORSO INTERDISCIPLINARE PER INTRODURRE E UTILIZZARE STRUMENTI MATEMATICI

Bice Cavallo, Gerarda Fattoruso, Maria Incoronata Fredella, Maria Grazia Olivieri, Massimo Squillante, Antonia Travaglione

143 5.1. Introduzione

144 5.2. Decidere: quale metodo e quale modello?

5.2.1. La decisione: situazioni e approcci diversi

5.3. Quali oggetti matematici per le decisioni?

5.3.1. Le Relazioni

5.3.2. Una struttura unificante: l'Alo-group

5.4. Fenomeni e modelli. Problemi di ottimizzazione: programmazione vs metodi multicriteriali 
5.4.1. I metodi multi-obiettivo (MODM) e $i$ metodi multi-attributo (MADM)

165 5.5. Un'applicazione dei metodi multicriteriali (AHP). Il porto di Napoli, un caso di studio

175 5.6. Conclusioni

177 6. Prospettive PeR UnA Didattica CRITICA E MUltidimensioNALE DELL'italiano

Pietro Maturi

6.1. Introduzione

6.2. Competenza linguistica e competenza comunicativa

6.3. Le Dieci tesi per l'educazione linguistica democratica del G.I.S.C.E.L.

181 6.4. Due modelli contrapposti: la didattica delle lingue classiche e quella delle lingue straniere

6.4.1. Una nuova sfida: la didattica dell'italiano L2

185 7. Riflessioni E SUGgeRIMENTI PER UNA SCUOLA CHE EDUCHI LA MENTE

Fabio Maria Risolo

7.1. Percorsi cognitivi e umanistici

7.2. Pratiche didattiche

7.2.1. Laboratorio di didattica contrastiva italiano/dialetto

7.2.2. Laboratori di scrittura creativa

7.2.3. Didattica della scrittura: dalla prescrittura alle scritture di sintesi, al saggio breve

8. VARIAZIONE LiNGUistica E PENSIERO CRITICO: ALCUNE RIFLESSIONI

Luca Marano

202

8.1. Introduzione

202

206

210

8.2. Pensiero critico e variazione linguistica

8.2.1. Il pensiero critico visto da un non filosofo: una breve riflessione

8.2.2. La variazione linguistica: definizione e caratteristiche

8.2.3. Variazione linguistica, pensiero critico e scuola: quale legame? Una riflessione su capacità di decisione e scelta consapevole

8.3. Breve analisi linguistica

8.3.1. Caratteristiche del "corpus" 
8.3.2. I fenomeni linguistici

8.3.2.1. Pronomi

8.3.2.2. Soggetto

8.3.2.3. Verbo

8.3.2.4. La struttura della frase

Sezione III - DIDATTICA E PENSIERO CRITICO: LEARNING BY DOING

9. Didattica del management. Quello che accade in aula ACCADE FUORI DALL'AULA

Luigi Maria Sicca

9.1. Introduzione

9.2. Griglia di lettura I: estensioni e sovrapposizioni

9.2.1. Organizzazioni da leggere e sovrapporre

9.2.1.1. Critical management studies e cultural symbolism

9.2.1.2. Tradurre, interpretare, tradire

9.3. Griglia di lettura II: ansia di contenitori e di contenimento

9.3.1. Le domande che gli studenti si (mi) pongono

9.3.2. Lo studente riflette su se stesso

9.4. Griglia di lettura III: la retorica delle competenze

9.4.1. Apprendimento adulto: si può insegnare il decision making?

9.4.2. Pedagogia elo andragogia: ma lo studente universitario è adulto?

9.5. Conclusioni: attraversiamo la strada

10. L'insegnamento del Diritto privato nella Relazione TRA “DIRITTO E REALTÀ"

Giuseppe Recinto

10.1. Premessa: la tradizionale tendenza a privilegiare modelli d'insegnamento deduttivi

10.2. Una possibile alternativa: il diritto come scienza pratica

10.3. Il conseguente approdo al learning by thinking and by doing: lo studio per problemi

10.3.1. La sistematicità nella trattazione degli argomenti, rispetto agli altri saperi e nella selezione del materiale didattico

10.3.2. L'"accertamento progressivo" delle capacità di analisi e di ragionamento dello studente 
254 10.4. La verifica dei c.dd. learning outcomes quale esperienza di relazione

11. La mia esperienza d'insegnamento della Fisica Mario Nicodemi

261

261

261

264

265

266

267

269

270

271

272

274

\section{Sezione IV - DidatTica e PENSIERo CRITICO: PROgetTARE I CONTESTI}

12. Lo STRUMENTO MUSICALE: PERCORSI DI APPRENDIMENTO Chiara Mallozzi e Luigi Marolda 12.1. Introduzione

12.2. Didattica dello strumento musicale. Ieri, oggi... e domani? 12.2.1. Articolazione del capitolo

12.3. A lezione di strumento: la narrazione e la didattica 12.3.1. Violino: lezione 1. Approccio allo strumento 12.3.2. Violino: lezione 2. La musica d'insieme Meditazione I 12.3.3. Violoncello: lezione 1. Un nuovo inizio 12.3.4. Violoncello: lezione 2. La valigia della tecnica Meditazione II

12.4. Conclusioni

13. ECOSISTEMI DI APPRENDIMENTO PER LO SVILUPPO DEL PENSIERO CRITICO

Luigi Proserpio

13.1. Introduzione

13.2. Insegnare il pensiero critico in una università di Economia e Management

13.3. Il caso da cui si traggono le generalizzazioni

13.4. Il concetto di ecosistema per l'apprendimento

13.5. (alcune) Metodologie per lo sviluppo di capacità critiche 13.5.1. Flipped classroom 13.5.2. Laboratori

13.5.3. Didattica basata su simulazioni e casi 13.5.4. Assignment-based classroom 13.5.5. Classi ibride

13.6. Parte tecnica dell'ecosistema didattico 13.6.1. Spazi fisici (e virtuali) 13.6.2. Software e hardware 13.6.3. Contenuti 
13.7. Le difficoltà di creazione di un ecosistema di apprendimento

13.8. I problemi e le barriere per l'adozione di metodi e supporti sofisticati

14. E-LEARNING E PENSIERO CRITICO: UNO SGUARDO ORGANIZZATIVO Davide Bizjak, Paolo Canonico, Stefano Consiglio, Ernesto De Nito, Teresa Anna Rita Gentile

14.1. Introduzione

14.2. E-learning come piattaforma organizzativa 14.3. E-learning e comunità organizzativa

14.4. Metodi di analisi dei casi di studio 14.4.1. Il case study pilota. L'Università degli Studi di Napoli "Federico II"

14.4.2. Case Study 1: L'Università di Dresda (Germania) 14.4.3. Case Study 2: Queen's University of Belfast (Regno Unito)

14.4.4. Case Study 3: L'Alma Mater Studiorum di Bologna

14.5. Quattro categorie organizzative per lo studio dell'e-learning 14.5.1. Strategia

14.5.2. Organizzazione

14.5.3. Utenti

14.5.4. Contesto

14.6. E-learning e pensiero critico

15. Il PENSIERO CRITICO NELL'UNIVERSITÀ TRA COSCIENZA, AUTONOMIA E LIBERTÀ DEL SOGGETTO

Natascia Villani

15.1. La coscienza critica

15.2. L'autonomia all'interno dell'Università

15.3. Verso un'educazione esistenziale

15.4. L'Università, il lavoro e la scuola

15.5. Il Corso di Laurea in Economia aziendale e Green Economy e l'accordo con Apple

15.6. Ricerca e azione nelle scuole secondarie 
361 Diario di bordo

Luigi Maria Sicca

369 Bibliografia

397 Indice dei nomi

$405 \quad$ Notizie sugli autori

407 Hanno scritto nella Collana punto org 


\section{Bibliografia}

Abrami, P.C., Bernard, R.M., Borokhovski, E., Wade, A., Surkes, M., Tamim, R., Zhang, D.A. (2008), Instructional interventions affecting critical thinking skills and dispositions: A stage one meta-analysis, Review of Educational Research, Vol. 78/4, pp. 1102-1134.

Aczel, J., Saaty, T.L. (1989), Procedures for Synthesizing Ratio Judgements, Journal of mathematical Psychology, Vol. 27/1, pp. 93-102.

Adeola, S.O., Adewale, S.O., Alese, K.B. (2013), Integrated E-learning System (IES) for the Nigeria Universities: An Architectural Overview, American Journal of Database Theory and Application, Vol. 2/1, pp. 1-8.

Al-Adwan, A., Al-Adwan, A., Smedley, J. (2013), Exploring Students Acceptance of E-learning Using Technology Acceptance Model in Jordanian Universities, International Journal of Education and Development using Information and Communication Technology, Vol. 9/2, pp. 4-18.

Alberici, A. (1999), Imparare sempre nella società conoscitiva, Torino, Paravia.

Alberici, A. (2008), La possibilità di cambiare. Apprendere ad apprendere come risorsa strategica per la vita, Milano, FrancoAngeli.

Al-Fadhli, S., Khalfan, A. (2009), Developing critical thinking in e-learning environment: Kuwait University as a case study, Assessment $\mathcal{E}$ Evaluation in Higher Education, Vol. 34/5, pp. 529-536.

Alfonzetti, G. (2002), La relativa non standard. Italiano popolare o italiano parlato?, Palermo, Centro di studi filologici e linguistici siciliani.

Alighieri, D. (1968), De vulgari eloquentia, a cura di P.V. Mengaldo, Padova, Antenore.

Allais, M. (1953), Le Comportement de l'Homme Rationnel devant le Risque: Critique des Postulats et Axiomes de l'Ecole Americaine, Econometrica, Vol. 21/4, pp. 503-546.

Al-Qahtani, A.A., Higgins, S.E. (2013), Effects of Traditional, Blended and E-learning on Students' Achievement in Higher Education, Journal of Computer Assisted Learning, Vol. 29/3, pp. 220-234. 
Andersen, E., Schiano, B. (2014), Teaching with cases: A practical guide, Boston, Harvard Business School Publishing.

Angelelli, R., Cali, G., Gueli, A. (a cura di) (2016), Una sfida ancora aperta, Insegnare. Reperibile online all'indirizzo: http://www.insegnareonline.com/rivista/oltre-lavagna/sfida-aperta.

Antonelli, G. (2011), Lingua, in A. Afribo e E. Zinato (a cura di), Modernità italiana, Roma, Carocci, pp. 15-52.

ANVUR (Agenzia Nazionale di valutazione del sistema Universitario e della Ricerca) (2014), Valutazione e diagnosi sugli esiti degli apprendimenti effettivi di carattere generalista dei laureandi nelle Università di Napoli Federico II, Lecce, Messina e Cagliari, Roma, ANVUR.

APA (American Philosophical Association) (1990), Critical Thinking: A Statement of Expert Consensus for Purposes of Educational Assessment and Instruction, The Delphi Report:, Research findings and recommendations prepared for the American Philosophical Association by P. Facione, Project Director.

Arcidiacono, F. (2015), Argumentation and reflexivity, in G. Marsico, R. Andrisano-Ruggieri e S. Salvatore (a cura di), Reflexivity and Psychology, Charlotte, Information Age Publishing, pp. 169-193.

Argyris, C. (1971), Management Information Systems: The Challenge to Rationality and Emotionality, Management Science, Vol. 17/6.

Argyris, C., Schön, D.A. (1978), Organisation learning, Readings, Addison Wesley.

Arnsperger, C. (2005), Critique de l'existence capitaliste, Paris, CERF.

Arrow, K.J. (1951), Social Choice and Individual Values, New York, Wiley.

Arrow, K.J., Raynaud, H. (1986), Social Choice and Multicriterion Decision-Making, Cambridge, Mit Press.

Arum, R., Roksa, J. (2011), Academically Adrift. Limited Learning on College Campuses, Chicago, University of Chicago Press.

Asterhan, C.S.C., Schwarz, B.B. (2009), Argumentation and Explanation in Conceptual Change: Indications from Protocol Analyses of Peer-to-Peer Dialog, Cognitive Science, Vol. 33, pp. 374-400.

Atabaki, A.M.S., Keshtiaray, N., Yarmohammadian, M.H. (2015), Scrutiny of Critical Thinking Concept, International Education Studies, Vol. 8/3, pp. 93-102.

Austin, J.L. $(1961)^{3}$, Philosophical Papers, Oxford, Oxford University Press [tr. it. (1990), Saggi filosofici, a cura di P. Leonardi, Milano, Guerini]. Austin, J.L. (1962), How to do things with words, Oxford, Oxford University Press [tr. it. (1987), Come fare cose con le parole, Genova, Marietti]. 
Ausubel, D. (1978), Educazione e processi cognitivi, Milano, Feltrinelli [ed. orig. (1968), Educational psychology: A cognitive view, New York, Holt, Rinehart \& Winston].

Bakhtin, M.M. (1981), The dialogical imagination: four essays by M.M. Bakhtin, Austin, University of Texas Press.

Baldacci, M. (2005), Unità di apprendimento e programmazione, Napoli, Tecnodid.

Banerjee, A.V., Duflo, E. (2014), (Dis)organization and Success in an Economics MOOC, American Economic Review, Vol. 104/5, pp. 514-518.

Barnard, C. (1938), The Functions of the Executives, Cambridge, Harvard University Press [tr. it. (1970), Le funzioni del dirigente, Torino, Utet].

Barrows, H.S., Tamblyn, R.M. (1980), Problem-based learning in medical education, New York, Springer.

Barry, J., Chandler, J., Clark, H. (2001), Between the Ivory Tower and the Academic Assembly Line, Journal of Management Studies, Vol. 38/1, pp. 87-101.

Basile, L., D’Apuzzo, L. (1997), Ranking and Weak Consistency in the A.H.P. Context, Rivista di Matematica per le Scienze Economiche e Sociali, Vol. 20/1, pp. 99-110.

Basile, L., D’Apuzzo, L., Di Lorenzo, E., Squillante, M. (2002), A.G.S. Ventre "Incontro con Kenneth Arrow", Napoli, La Città del Sole.

Bauman, Z. (2006), Vita liquida, Roma-Bari, Laterza.

Bauman, Z., Mazzeo, R. (2011), Conversazioni sull'educazione, Trento, Erickson.

Beaudoin, M.F., Kurtz, G., Eden, S. (2009), Experiences and opinions of e-learners: What works, what are the challenges, and what competencies ensure successful online learning, Interdisciplinary Journal of E-learning and Learning Objects, Vol. 5, pp. 275-298. Reperibile online all'indirizzo: http://www.ijello.org/Volume5/ IJELLOv5p275-289Beaudoin665.pdf.

Beckhard, R. (1969), Organization Development: Strategies And Models, Reading, Addison-Wesley.

Beckmann, J., Weber, P. (2016), Cognitive presence in virtual collaborative learning: Assessing and improving critical thinking in online discussion forums, Interactive Technology and Smart Education, Vol. 13/1, pp. 52-70.

Begg, M., Hellaway, R., Dewhurst, D., Macleod, H. (2011), Logos and Mythos: The Political Dilemmas of Web 2.0 in an Accreditation-driver Educational Environment, in R. Land e S. Bayne (a 
cura di), Digital Difference: Perspective on Online Learning, Rotterdam, Sense Publishers, pp. 73-82.

Bell, B.S., Federman, J.E. (2013), E-learning in Postsecondary Education, The Future of Children, Vol. 23/1, pp. 165-185.

Belton, S., Stewart, T.S. (2002), Multiple Criteria Decision Analysis. An Integrated Approach, Massachusetts, Kluwer Academic Publishers.

Benincà, P., Frison, L., Salvi, G. (1988), L'ordine degli elementi della frase e le costruzioni marcate, in L. Renzi (a cura di), Grande grammatica italiana di consultazione, vol. 1: La frase. I sintagmi nominale e preposizionale, Bologna, Il Mulino, pp. 115-226.

Bennis, W. (1969), Organization Development: its nature, origin and prospects, Reading, Addison-Wesley.

Bereiter, C., Scardamalia, M. (1987), The Psychology of Written composition, Hillsdale, Lawrence Erlbaum Associates [tr. it. (1995), Psicologia della composizione scritta, a cura di D. Corno, Firenze, La Nuova Italia].

Berger, P.L., Luckmann, T. (1966), The Social Construction of Reality: A Treatise in the Sociology of Knowledge, Garden City, Anchor Books [tr. it. (1969), La realtà come costruzione sociale, Bologna, Il Mulino].

Berlyne, D.E. (1960), Conflict, Arousal and Curiosity, New York, McGrawHill.

Berruto, G. (1985), Dislocazioni a sinistra e grammatica dell'italiano parlato, in A. Franchi De Bellis e L.A. Savoia (a cura di), Sintassi e morfologia della lingua italiana d'uso. Teorie e applicazioni descrittive, Atti del XVII Congresso Internazionale di Studi della SLI (Urbino, 11-13 settembre 1983), Roma, Bulzoni, pp. 59-82.

Berruto, G. (1987), Sociolinguistica dell'italiano contemporaneo, Roma, La Nuova Italia Scientifica.

Berruto, G. (1995), Fondamenti di sociolinguistica, Roma-Bari, Laterza.

Berruto, G. (2017), What is changing in Italian today? Phenomena of restandardization in syntax and morphology: an overview, in M. Cerruti, C. Crocco e S. Marzo (a cura di), Towards a New Standard Theoretical and Empirical Studies on the Restandardization of Italian, Berlin, De Gruyter, pp. 31-60.

Bertagna, G. (2016), Eredità di una vecchia ed esigenze di una nuova formazione, Pedagogika.it, Vol. 20/3, pp. 49-55.

Bertinetto, P.M. (1986), Tempo aspetto e azione nel verbo italiano. Il sistema dell'indicativo, Firenze, Accademia della Crusca.

Betti, E. (1991), Diritto, metodo, ermeneutica. Scritti scelti, Milano, Giuffrè. 
Blanche-Benveniste, C. (2006), Detachment constructions, in K. Brown (a cura di), Encyclopedia of Language and Linguistics, vol. III, Oxford-New York, Elsevier, pp. 477-484.

Bick, E. (1968), The experience of the skin in early object-relations, International Journal of Psychoanalysis, Vol. 49, pp. 484-486.

Bion, W.R. (1961), Experiences in groups and other papers, London, Tavistock Publications [tr. it. (1971), Esperienze nei gruppi, Roma, Armando].

Bobbio, N. (2011), Sul ragionamento dei giuristi, in Saggi sulla scienza giuridica, Torino, Giappichelli.

Boisvert, J. (1999), La formation de la pensée critique; théorie et pratique, Saint-Laurent, Éditions du Renouveau Pédagogique.

Bok, D. (1982), Beyond the Ivory Tower: Social Responsibilities of the Modern University, Cambridge, Harvard University Press.

Boncori, I., Sicca, L.M., Bizjak, D. (2015), Resistance in Academia: Workload Models as Instruments of Transparency or as a Form of Managerial Panopticon?, European Academy of Management, EURAM (Warsaw, 17-21 June).

Boutinet, J.P. (2004), La personne adulte et sa construction identitaire prise aux dilemmes de ses compétences in Pellois, C., Vivier, J., Aubret, J., Boutinet, J.P., Bilan de compétences et mutations: l'accompagnement de la person, Bruxelles, Peter Lang.

Bowlby, J. (1969), Attachment and loss, vol. I: Attachment, New York, Basic Books [tr. it. (1972), Attaccamento e perdita, vol. I: L'attaccamento alla madre, Torino, Boringhieri].

Bowlby, J. (1973), Attachment and loss, vol. II: Separation, Anxiety and Anger, London, the Hogarth Press [tr. it. (1975), Attaccamento e perdita, vol. II: Separazione, Ansia e Rabbia, Torino, Boringhieri].

Bowlby, J. (1980), Attachment and loss, vol. III: Loss: Sadness and Depression, New York, Basic Books [tr. it. (1980), Attaccamento e perdita, vol. III: Perdita: tristezza e depressione, Torino, Boringhieri].

Boyd, R., Kuhn, T. (1979), Metaphor and Theory Change: What is "Metaphor" a Metaphor for? Metaphor in Science, in A. Ottony (a cura di), Metaphor and Thought, Cambridge, Cambridge University Press.

Breton, M. (2001), Neighborhood resiliency, Journal of Community Practice, Vol. 19/1, pp. 21-36.

Bruner, J. (1999), The Process of Education, a Landmark in educational theory, Harvard, Harvard University Press [tr. it. (1999), Il Processo Educativo. Dopo Dewey, Roma, Armando]. 
Buckingham, D. (2006), Media education. Alfabetizzazione, apprendimento e cultura contemporanea, Trento, Erickson.

Burbules, N., Berk, R. (1999), Critical Thinking and Critical Pedagogy: Relations, Differences, and Limits, in T. Popkewits e L. Fendler (a cura di), Critical Theories in Education, New York, Routledge.

Burke, W. (1982), Organization Development: Principles and Practices, Boston, Little Brown \& Co.

Burrell, G., Morgan, G. (1979), Sociological Paradigms and Organizational Analysis, London, Heinemann Educational Books.

Cambi, F. (2004), Saperi e competenze, Roma-Bari, Laterza.

Cambi, F. (2006), Abitare il disincanto. Una pedagogia per il postmoderno, Torino, Utet.

Cantù, P., Testa, I. (2006), Teorie dell'argomentazione. Introduzione alle logiche del dialogo, Milano, Bruno Mondadori.

Capano, G., Regini, M. (a cura di) (2015), Come cambia la governance. Università italiane ed europee a confronto, Roma, Fondazione CRUI.

Capobianco, R. (2017), Verso la società delle competenze. La prospettiva pedagogica, Milano, FrancoAngeli.

Cappetta, R., Magni, M. (2015), Locus of control and individual learning: the moderating role of interactional justice, International Journal of Training and Development, Vol. 19/2, pp. 110-124.

Cappetta, R. (2016), Apprendimento e Formazione, in S. Salvemini (a cura di), Organizzazione Aziendale, Milano, Egea.

Carril, P.C.M., Sanmamed, M.G., Sellés, N.H. (2013), Pedagogical Roles and Competencies of University Teachers Practicing in the E-learning Environment, The International Review of Research in Open and Distributed Learning, Vol. 14/3, pp. 462-487.

Castoldi, M. (2009), Valutare le competenze. Percorsi e strumenti, Roma, Carocci. Castoldi, M. (2011), Progettare per competenze. Percorsi e strumenti, Roma, Carocci.

Castoldi, M. (2013), Curricolo per competenze. Percorsi e strumenti, Roma, Carocci.

Castoldi, M. (2017), Costruire unità di apprendimento. Guida alla progettazione a ritroso, Roma, Carocci.

Castoriadis, C. (1975), L'institution Imaginaire de la Société, Paris, Seuil.

Cattani, A., Cantù, P., Testa, I. (2009), La svolta argomentativa. 50 anni dopo Perelman e Toulmin, Casoria, Loffredo.

Cavallo, B., D’Apuzzo, L. (2009), A general unified framework for pairwise comparison matrices in multicriterial methods, International Journal of Intelligent Systems, Vol. 24/4, pp. 377-398. 
Cavallo, B., D'Apuzzo, L., Squillante, M. (2012), About a consistency index for pairwise comparison matrices over a divisible alo-group, International Journal of Intelligent Systems, Vol. 27/2, pp. 153-175.

Cavallo, B., D’Apuzzo, L., Squillante, M. (2014), A multi-criteria decision making method for sustainable development of Naples port city-area, Quality \& Quantity, Vol. 49/4, pp. 1647-1659.

Cavallo, B., D'Apuzzo, L., Vitale, G. (2018), Reformulating Arrow's conditions in terms of cardinal pairwise comparison matrices defined over a general framework, Group Decision and Negotiation, Vol. 27/1, pp. 107-127.

Chen, K.C., Chuang, K.C. (2016), Building a Cooperative Learning Environment in a Flipped Classroom, Academy of Educational Leadership Journal, Vol. 20/2, pp. 8-15. Reperibile online all'indirizzo: https:// www.abacademies.org/articles/aeljvol20no22016.pdf.

Chomsky, N. (1965), Aspects of the Theory of Syntax, Cambridge, MIT Press.

CNIPA (Centro Nazionale per l'Informatica nella Pubblica Amministrazione) (2007)2, Vademecum per la realizzazione di progetti formativi in modalità e-learning nelle pubbliche amministrazioni, Quaderni Cnipa, n. 32, pp. 365-366.

Cochrane, T., Bateman, R. (2010), Smartphones give you wings: Pedagogical affordances of mobile Web 2.0, Australasian Journal of Educational Technology, Vol. 26/1, pp. 142-152.

Cohen, W.M., Levinthal, D.A. (1990), Absorptive capacity: A new perspective on learning and innovation, Administrative Science Quarterly, Vol. 35/1, pp. 128-152.

Comoglio, M. (2002), La valutazione autentica, Orientamenti Pedagogici, Vol. 49/1, pp. 93-112.

Coppola, C., Mollo, M., Pacelli, T. (2011), An experience of social rising of logical tools: the role of language, International Journal for Mathematics Teaching and Learning, pp. 1-15.

Corbetta, P. (1999), Metodologia e tecniche della ricerca sociale, Bologna, Il Mulino.

Corbetta, P. (2014)², Metodologia e tecniche della ricerca sociale, Bologna, Il Mulino.

Corno, D. (1999), La scrittura. Scrivere, riscrivere, sapere di sapere, Catanzaro, Rubbettino.

Cortelazzo, M., Zolli, P. (1999), Il nuovo etimologico. DELI - Dizionario Etimologico della Lingua Italiana, Bologna, Zanichelli. 
Council of the European Union (2014), Recommendation of 28 June 2011 on policies to reduce early school leaving. Reperibile online all'indirizzo: http://ec.europa.eu/dgs/education_culture/repository/education/ policy/strategic-framework/doc/esl-group-report_en.pdf.

Coupland, N., Kristiansen, T. (2011), Critical perspectives on language (de)standardization, in T. Kristiansen e N. Coupland (a cura di), Standard languages and language standards in a changing Europe, Oslo, Novus Press, pp. 11-35.

Creswell, J.W. (2014)4, Research Design: Qualitative, Quantitative, and Mixed Methods Approaches, Thousand Oaks, Sage Publication.

Cunliffe, A.L. (2004), On becoming a critically reflexive practitioner, Journal of Management Education, Vol. 28/4, pp. 407-426.

Cyrulnik, B., Malaguti, E. (a cura di) (2005), Costruire la resilienza. La riorganizzazione positiva della vita e la creazione di legami significativi, Trento, Erickson.

D'Achille, P. (1990), Sintassi del parlato e tradizione scritta della lingua italiana, Roma, Bonacci.

D’Apuzzo, L., Marcarelli, G., Squillante, M. (2009), Analysis of Qualitative and Quantitative Rankings in Multicriteria Decision Making, in T. Lux e M. Faggini (a cura di), Coping with the complexity of economics, Milan-Berlin-Heidelberg-New York, Springer, parte IV, pp. 157-170.

Da Re, F. (2013), La didattica per competenze. Apprendere competenze, descriverle e valutarle, Milano, Pearson.

Davis, F.D. (1989), Perceived usefulness, perceived ease of use, and user acceptance of information technology, MIS Quarterly, Vol. 13/3, pp. 319-340.

Deakin Crick, R., Stringher, C., Ren, K. (a cura di) (2014), Learning to Learn. International perspectives from theory and practice, New York, Routledge.

De Bono, E. (2013), Sei cappelli per pensare. Manuale pratico per ragionare con creatività ed efficacia, Milano, BUR.

de Finetti, B. (1974), Theory of probability, New York, John Wiley \& Sons.

De Liso, G., Esposito, V., La Sala, A., Olivieri, M.G., Squillante, M. (2017), L'evoluzione del controllo organizzativo: l'approccio multi-criteriale alla valutazione delle performance, in M. Squillante (a cura di), Decidere nella complessità, Roma, Edicampus edizioni, pp. 61-96.

Delors, J. (1997), Nell'educazione un tesoro, Roma, Armando.

De Mauro, T. (1963), Storia linguistica dell'Italia unita, Bari, Laterza. 
De Mauro, T. (2015), Prefazione, in F. Piro, Manuale di Educazione al pensiero critico. Comprendere e Argomentare, Napoli, Editoriale Scientifica.

De Mauro, T. (2017), Storia linguistica dell'Italia unita, Bari, Laterza.

De Mauro, T., Lodi, M. (1993), Lingua e dialetti, Roma, Editori Riuniti.

Demetrio, D., Alberici, A. (2004), Istituzioni di Educazione degli adulti, Milano, Guerini e Associati.

D’Errico, F. (2016), Fuor di metafora. Sette osservazioni sull'improvvisazione musicale, Napoli, Editoriale Scientifica.

Deschacht, N., Goeman, K. (2015), The effect of blended learning on course persistence and performance of adult learners: A difference-in-differences analysis, Computers $\mathcal{E}$ Education, Vol. 87/100, pp. 83-89.

Dewey, J. (1910), How we think, Boston, Heath \& Co [tr. it. (1961), Come pensiamo, Una riformulazione del rapporto fra il pensiero riflessivo e l'educazione, Firenze, La Nuova Italia].

Dewey, J. (1916), Democracy and Education: an introduction to the philosophy of education, New York, Macmillan [tr. it. (1949), Democrazia e educazione, Firenze, La Nuova Italia].

Dewey, J. (1990), Esperienza e natura, Milano, Mursia [ed. orig. (1925), Experience and Nature, Chicago-London, Open Court Publishing].

Dewey, J. (1996), Esperienza e educazione, Firenze, La Nuova Italia [ed. orig. (1938), Experience and Education, New York, The Macmillan Company].

Dewey, J. (2014), Esperienza e educazione, ed. it. a cura di F. Cappa, Milano, Raffaello Cortina.

Dijk, T.A. (van) (1977), Text and Context Explorations in the Semantics and Pragmatics of Discourse, London, Longman [tr. it. (1980), Testo e contesto, Semantica e pragmatica del discorso, Bologna, Il Mulino].

Di Rienzo, P. (2008), Una visione ecologica dell'apprendimento. Contesti formativi dell'apprendere ad apprendere, in A. Alberici (a cura di), La possibilità di cambiare. Apprendere ad apprendere come risorsa strategica per la vita, Milano, FrancoAngeli.

Dudley, L.W., Davis, H.H., McGrady, D.G. (2001), Using an investment project to develop professional competencies in introduction to financial accounting, Journal of Education for Business, Vol. 76/3, pp. 125-131.

Du Gay, P., Salaman, G. (1992), The cult[ure] of the customer, Journal of Management Studies, Vol. 29/5, pp. 615-633. 
Dumitru, D., Bigu, D., Elen, J. et al. (2018), A European Review on Critical Thinking educational practices in Higher Education Institutions, UTAD.

Dumont, H., Istance D., Benavides, F. (a cura di) (1993), Projet guide "Environnements pédagogiques novateurs" Comment apprend-on? La recherche au service de la pratique, Paris, OCDE.

Dwyer, C.P., Boswell, A., Elliott, M.A. (2015), An Evaluation of Critical Thinking Competencies in Business Settings, Journal of Education for Business, Vol. 90/5, pp. 260-269.

Eemeren, F.H. (van), Grootendorst, R. (1984), Speech Acts in argumentative discussions, Dordrecht, Foris Publications.

Eemeren, F.H. (van), Grootendorst, R. (1992), Argumentation, communication and fallacies. A pragma-dialectical perspective, Hillsdale, Lawrence Erlbaum Associates.

Eemeren, F.H. (van), Grootendorst, R., Snoeck Henkemans, F. (1996), Fundamentals of argu-mentation theory: A handbook of historical backgrounds and contemporary developments, Mahwah, New Jersey, Lawrence Erlbaum Associates.

Elder, L., Paul, R. (2006), The Miniature Guide to Critical Thinking Concepts and Tools, Dillon Beach, Foundation for Critical Thinking Press. Reperibile on line all'indirizzo: https://www.criticalthinking.org/ files/Concepts_Tools.pdf.

Elder, L., Paul, R. (2009), The Aspiring Thinker's Guide to Critical Thinking, Dillon Beach, Foundation for Critical Thinking Press.

Ennis, R.H. (1962), A Concept of Critical Thinking, Harvard Educational Review, Vol. 32/1, pp. 81-111.

Ennis, R.H. (1987), A taxonomy of critical thinking dispositions and abilities, in J. Baron e R. Sternberg (a cura di), Teaching thinking skills: theory and practice, New York, W.H. Freeman, pp. 9-26.

Ennis, R.H. (1989), Critical thinking and subject specificity: Clarification and needed research, Educational Researcher, Vol. 18/3, pp. 4-10.

Ennis, R.H. (1991), Critical thinking: a streamlined conception, Teaching Philosophy, Vol. 14/1, pp. 5-25.

Ennis, R.H. (1993), Critical Thinking Assessment, Theory into Practice, Vol. 32/3, pp. 179-186.

Ennis, R.H. (2011), Critical Thinking: reflection and perspective, part 1, Inquiry: Critical Thinking Cross the Disciplines, Vol. 26/1, pp. 1-65.

Ennis, R.H. (2015), Critical thinking: a streamlined conception, in M. Davies e R. Barnett (a cura di), The Palgrave handbook of critical thinking in higher education, New York, Palgrave Macmillan, pp. 31-47. 
European Commission (2016), Developing future skills in higher education, Bruxelles.

Ewan, C., Calvert, D. (2000), The Crisis of Scientific Research, in J. Garrick e C. Rhodes (a cura di), Research and Knowledge at Work: Perspectives, Case-studies and Innovative Strategies, London, Routledge, pp. 51-74.

Facione, N.C., Facione, P.A., Sánchez, C.A. (1994), Critical thinking disposition as a measure of competent clinical judgment: The development of the California Critical Thinking Disposition Inventory, Journal of Nursing Education, Vol. 33/8, pp. 345-350.

Falzea, A. (1998), La Costituzione e l'ordinamento, Rivista di diritto civile, Vol. 44/3, pp. 261-300.

Ferrari, P.L. (2002), Developing language through communication and conversion of semiotic systems, in A.D. Cockburn e E. Nardi (a cura di), Proc. of the 26th Conf. of the Intern. Group for the Psychology of Math, Ed. Norwich, vol. 2, pp. 353-360.

Foerster, H. (von) (1973), On constructing a reality, in Watzlawick, P., (1984), The invented reality, New York, W.W. Norton and Co.

Foerster, H. (von) (1991), Through the eyes of the other, in Research and Reflexivity, London, F. Steier [tr. it. (1996), Attraverso gli occhi dell'altro, Milano, Guerini e Associati].

Ford, J.D., Ford, L.W., D'Amelio, A. (2008), Resistance to change: The rest of the story, Academy of Management Review, Vol. 33/2, pp. 362-377.

Forte, P. (2017), La persona nella decisione amministrativa, in M. Squillante (a cura di), Decidere nella complessità, Roma, Edicampus edizioni, pp. 7-59.

Frabboni, F. (1992), Manuale di didattica generale, Roma-Bari, Laterza.

Freire, P. (2002), La pedagogia degli oppressi, Torino, EGA Edizioni.

French, S. (1986), Decision Theory: An Introduction to the Mathematics of Rationality, New York, Ellis Horwood Ltd.

French, W.L., Bell, C.H. Jr. (1999), Organization Development: Behavioral Science Interventions for Organization Development, Saddle River, Prentice-Hall.

Freschi, A.M. (a cura di) (2006), Insegnare uno strumento. Riflessioni e proposte metodologiche su linearità/complessità, Torino, EDT.

Friedrich, J. (2012), L'idée d'instrument psychologique chez Vygotski, Rivista italiana di filosofia del linguaggio, Vol. 6/2, pp. 189-201.

Gadamer, H.-G. (1983), Verità e metodo, tr. it. a cura di G. Vattimo, Milano, Bompiani. 
Gagliardi, P. (a cura di) (1995), Le Imprese come culture, Torino, Isedi.

Gambarelli, G., Pederzoli, G. (1992), Metodi di decisione, Milano, Hoepli. Gardner, H. (1983), Frames of Mind. The Theory of Multiple Intelligences, New York, Basic Books [tr. it. (1987), Formae Mentis. Saggio sulla pluralità dell'intelligenza, Milano, Feltrinelli].

Gardner, H. (1984), The Mind's New Science, New York, Basic Books [tr. it. (1988), La nuova scienza della mente, Milano, Feltrinelli].

Garrison, D.R., Anderson, T. (2003), E-learning in the 21st century: A framework for research and practice, London, Routledge.

Gergen, K.J. (1973), Social Psychology as History, Journal of Personality and Social Psychology, Vol. 26/2, pp. 309-320.

Gharib, M., Zolfaghari, M., Mojtahedzadeh, R., Mohammadi, A., Gharib, A. (2016), Promotion of critical thinking in e-learning: a qualitative study on the experiences of instructors and students, Advances in Medical Education and Practice, Vol. 7, pp. 271-279.

Glaser, B., Strauss, A. (1967), The Discovery of Grounded Theory. Strategies for Qualitative Research, Chicago, Aldine Publishing Company [tr. it. (2009), La scoperta della GT, Roma, Armando].

Glaser, E.M. (1941), An Experiment in the Development of Critical Thinking, New York, Teacher's College, Columbia University.

Glaser, R. (1984), Education and Thinking: The Role of Knowledge, American Psychologist, Vol. 39/2, pp. 93-104.

Glasersfeld, E. (von) (1990), An exposition of constructivism: Why some like it radical, in R.B Davis, C.A. Maher e N. Noddings (a cura di), Monographs of the Journal for Research in Mathematics Education, Reston, Virginia, National Council of Teachers of Mathematics, Vol. 4, pp. 19-29.

Greco, S., Figueira, J., Ehrgott, M. (2005), Multiple criteria decision analysis, International Series in Operations Research $\mathcal{E}$ Management Science, Vol. 142, pp. 507-562.

Grice, P. (1957), Meaning, Philosophical Review, Vol. 66, pp. 377-388, ora in Id. (1989), Studies in the Way of Words, Cambridge, Harvard University Press, pp. 213-223.

Grice, P. (1975), Logic and Conversation, in P. Cole e J.L. Morgan (a cura di), Syntax and Semantics, vol. 3: Speech Acts, New York, Academic Press, pp. 41-58, ristampato in Id., Studies in the Way of Words, Cambridge, Harvard University Press, pp. 22-40 [tr. it. (2003), Logica e conversazione, a cura di M. Sbisà, in Filosofia del linguaggio, a cura di A. Iacona e E. Paganini, Milano, Cortina, pp. 221-244]. 
Griffiths, T.L., Steyvers, M., Firl, A. (2007), Google and the mind: Predicting fluency with PageRank, Psychological Science, Vol. 18/12, pp. 1069-1076.

Grize, J.-B. (1982), De la logique à l'argumentation, Genève, Droz.

Grize, J.-B., Piéraut-Le Bonniec, G. (1983), La contradiction: essai sur le opérations de la pensée, Paris, Presse Universitaires de France.

Grossi, P. (2017), L'invenzione del diritto, Roma-Bari, Laterza.

Guerriero, A.R. (a cura di) (2002), Laboratorio di scrittura, Firenze, La Nuova Italia.

Hansen, D. (2011), The Teacher and the World: A Study of Cosmopolitanism as Education, New York, Routledge.

Hart Research Associates (2013), It Takes More Than A Major: Employer Priorities for College Learning and Student Success, Connecticut Avenue, Washington, 10 april 2013. Reperibile online all'indirizzo: http://www.aacu.org/leap/presidentstrust/compact/2013SurveySummary.cfm.

Harvard Law School, The case study Teaching Method. Reperibile online all'indirizzo: http://casestudies.law.harvard.edu/the-case-studyteaching-method/.

Hautamäki, J., Arinen, P., Eronen, S., Hautamäki, A., Kupianien, S., Lindblom, B., Niemivirta, M., Pakaslahti, L., Rantanen, P., Scheinin, P. (2002), Assessing Learning-to-Learn: A Framework. Helsinki: Centre for Educational Assessment, Helsinki, National Board of Education.

Heilmann, L. (1966), Introduzione a R. Jakobson, Saggi di linguistica generale, Milano, Feltrinelli, pp. VII-XXV.

Holmes, B., Gardner, J. (2006), E-learning: Concepts and practice, London, Sage Publications.

Hung, W., Jonassen, D.H. (2008), All Problems are Not Equal: Implication for Problem-Based Learning, Interdisciplinary Journal of Problem-Based Learning, Vol. 2/2, pp. 6-28.

Hymes, D. (1966), Two types of linguistic relativity, in Bright, W., Sociolinguistics, The Hague, Mouton, pp. 114-158.

Hymes, D. (1972), On comunicative competence, in J.B Pride e J. Holmes (a cura di), Sociolinguistics. Selected Readings, Harmondsworth, Penguin, pp. 269-293 [tr. it. (1979), La competenza comunicativa, in Universali linguistici, a cura di F. Ravazzoli, Milano, Feltrinelli, pp. 212-243].

Iannaccone, A., Convertini, J., Perret-Clermont, A.-N. (2016), Je te raconte une histoire pour t'aider à comprendre. Pluralité de perspectives 
conversationnelles et actualisation des pratiques argumentatives chez l'enfant, Congress of SSRE “Où s'arrête l'école? Transformations et déplacements des frontières éducatives", Lausanne, July 2016.

Iannaccone, A., Perret-Clermont, A.-N. (2014), Regole ed eccezioni: a propositio del ruolo delle interazioni sociali nei processi di apprendimento e nello sviluppo cognitivo, in A. Smorti (a cura di), L'eccezione e la regola: opposizioni, convergenze, paradossi, Firenze, SEID, pp. 97-122.

Iannaccone, A., Zittoun, T. (2014), Overview: The activity of thinking on social spaces, in T. Zittoun e A. Iannaccone (a cura di), Activities of Thinking in Social Spaces, New York, Nova Science Publishers, pp. 1-12.

Inhelder, B., Sinclair, H., Bovet, M. (1974), Apprentissage et structures de la connaissance, Paris, Presses Universitaires de France.

Irti, N. (1999)4 , L'età della decodificazione, Milano, Giuffrè.

Jain, P., Purswani, G. (2016), Disruptive innovation in higher education: challenges in application of e-learning in conventional university system, International Journal of Research in IT and Management, Vol. 6/2, pp. 34-41.

Jakobson, R., Lévi-Strauss, C., Voegelin, C.F., Sebeok, T.A. (a cura di) (1953), Results of the Conference of Anthropologists and Linguists, supplement to International Journal of American Linguistics, Vol. 19/2 [tr. it. (1966), Antropologi e linguisti. Bilancio di un convegno, a cura di L. Heilmann, Milano, Feltrinelli, pp. 5-21].

Johnson-Laird, Ph.N. (1983), Mental Models, Cambridge, Cambridge University Press [tr. it. (1988), Modelli mentali. Verso una scienza cognitiva del linguaggio, dell'inferenza e della coscienza, Bologna, Il Mulino].

Keleman, K., Garcia, J., Lovelace, K. (1995)², Management Incidents: Role Plays for Management Development, Dubuque, Kendall/Hunt Publishing.

Knights, D., Willmott, H. (2007), Introducing organizational behaviour $\mathcal{E}$ management, London, Thomson Learning.

Knowles, M.S. (1973), The adult learner, Houston, Gulf Publishing Company [tr. it. (1993), Quando l'adulto impara, Milano, FrancoAngeli].

Knowles, M.S., Holton, E.F. III, Swanson, R.A. (2008), Quando l'adulto impara, Milano, FrancoAngeli.

Knowles M.S., Holton E.F. III, Swanson R.A. (2016), Quando l'adulto impara. Andragogia e sviluppo della persona, Milano, FrancoAngeli. 
Koch, P. (2014), La scelta manzoniana tra selezione e ristandardizzazione, in P. Danler e C. Konecny (a cura di), Dall'architettura della lingua italiana all'architettura linguistica dell'Italia. Saggi in omaggio a Heidi Siller-Runggaldier, Frankfurt am Main, Peter Lang, pp. 75-102.

Kolb, D.A. (1984), Experiential Learning: experience as the source of learning and development, Englewood Cliffs, Prentice Hall.

Krovetz, M.L. (1999), Resiliency: A Key Element for Supporting Youth At-Risk, The Clearing House, Vol. 73/2, pp. 121-123.

Kruger, J., Dunning, D. (1999), Unskilled and unaware of it: How difficulties in recognizing one's own incompetence lead to inflated self-assessments, Journal of Personality and Social Psychology, Vol. 77/6, pp. 1121-1134.

Kukulska-Hulme, A., Traxler, J. (a cura di) (2005), Mobile Learning: A Handbook for Educators and Trainers, London-NewYork, Routledge.

Kulig, J.C. (2000), Community Resiliency: the potential for community health nursing theory development, Public Health Nursing, Vol. 17/5, pp. 374-385.

Kunda, G. (1992), Engineering Culture. Control and Commitment in a HighTech Corporation, Philadelphia, Temple University Press [tr. it. (2000), L'ingegneria della cultura. Controllo, appartenenza e impegno in un'impresa ad alta tecnologia, Torino, Edizioni Comunità].

Kurilovas, E., Kubilinskiene, S., Dagiene, V. (2014), Web 3.0-Based Personalisation of Learning Objects in Virtual Learning Environments, Computers in Human Behavior, Vol. 30, pp. 654-662.

Lage, M., Platt, G., Treglia, M. (2000), Inverting the classroom: A gateway to creating an inclusive learning environment, Journal of Economic Education, Vol. 31/1, pp. 30-43.

Lambrecht, K. (1994), Information structure and sentence form, Cambridge, Cambridge University Press.

Land, R., Bayne, S. (a cura di) (2011), Digital difference: Perspectives on online learning, Rotterdam, Sense Publishers.

Ledgeway, A. (2008), Sulla storia dei verbi copulari dei dialetti dell'alto Meridione: il caso napoletano, The Italianist, Vol. 28/2, pp. 281-303.

Lehmann, D.R., Nisbett, R.E. (1990), Effects of teaching statistical laws on reasoning about everyday problems, Journal of Education Psychology, Vol. 87/1, pp. 33-46.

Leitao, S. (2000), The potential of argument in knowledge building, $\mathrm{Hu}$ man Development, Vol. 43/6, pp. 332-360. 
Lerner, A.J., Loewe, F. (1956), My fair lady, New York, Mark Hellinger Theatre.

Lettieri, N. (2017), Tempo, decisioni, diritto. Una lettura giuridica dell'intertemporal choice, in M. Squillante (a cura di), Decidere nella complessità, Roma, Edicampus edizioni, pp. 146-166.

Levy, Y., Ramim, M.M. (2017), The e-learning skills gap study: Initial results of skills desired for persistence and success in online engineering and computing courses, in Y. Eshet-Alkalai, I. Blau, A. Caspi, N. Geri, Y. Kalman e V. Silber-Varod (a cura di), Proceeding of the Chais 2017 Conference on Innovative and Learning Technologies Research, Raanana, The Open University of Israel, pp. 57-68.

Lewis, M. (2017), Un'amicizia da Nobel. Kahneman e Tversky, l'incontro che ha cambiato il nostro modo di pensare, Milano, Raffaello Cortina.

Lin, W.S., Wang, C.H. (2012), Antecedences to Continued Intentions of Adopting E-learning System in Blended Learning Instruction: A Contingency Framework Based on Models of Information System Success and Task-technology Fit, Computers \& Education, Vol. 58/1, pp. 88-99.

Linell, P. (2009), Rethinking Language, Mind and World Dialogicality, Charlotte, Information Age Publishing.

Lipman, M. (2002), Pratica filosofica e riforma dell'educazione. La filosofia con i bambini, in A. Cosentino (a cura di), Filosofia e formazione. 10 anni di Philosophy for Children in Italia (1991-2001), Napoli, Liguori, pp. 11-27.

Lipman, M. (2002), P4C e pensiero critico, in A. Cosentino (a cura di), Filosofia e formazione. 10 anni di Philosophy for Children in Italia (19912001), Napoli, Liguori, pp. 43-46.

Lipman, M. (2005), Educare al pensiero, Milano, Vita e Pensiero.

Liu, O.L., Frankel, L., Roohr, K.C. (2014), Assessing Critical Thinking in Higher Education: Current State and Directions for Next-Generation Assessment, ETS Research Reports Series, pp. 1-23.

Loiodice, I. (2004), Non perdere la bussola. Orientamento e formazione in età adulta, Milano, FrancoAngeli.

Lovelace, K.J., Eggers, F., Dyck, L.R. (2016), I Do and I Understand: Assessing the Utility of Web-based Management Simulations to Develop Critical Thinking Skills, Academy of Management Learning and Education, Vol. 15/1, pp. 100-121.

Louis, M.R. (1981), A Cultural Perspective on Organizations: the Need for and Consequences of Viewing Organizations as Culture-Bearing Milieux, Human Systems Management, Vol. 2/4, pp. 246-258. 
Louis, M.R. (1983), Organizations as Culture-Bearing Milieux, in L.R. Pondy, P.J. Frost, G. Morgan e T.D. Dandridge (a cura di), Organizational Symbolism, Greenwich, JAI.

Luhmann, N., Schorr, K.E. (1988), Il sistema educativo. Problemi di riflessività, Roma, Armando.

Lyons, J. (1968), Introduction to theoretical linguistics, Cambridge, Cambridge University Press [tr. it. (1971), Introduzione alla linguistica teorica, Roma-Bari, Laterza].

MacKnight, C. (2000), Teaching Critical Thinking through Online Discussions, Educause Quarterly, Vol. 23/4, pp. 38-41.

Maanen (van), J. (1979a), Reclaiming Qualitative Methods for Organizational Research: a Preface, Administrative Science Quarterly, Vol. 24/4, pp. 520-526.

Maanen (van), J. (1979b), The Fact of Fiction in Organizational Ethnography, Administrative Science Quarterly, Vol. 24/4, pp. 539-550 [tr. it. (1995), La realtà dell'invenzione nell'etnografia delle organizzazioni, in Gagliardi, P., Le imprese come culture, Torino, Utet].

Magni, M., Paolino, C., Cappetta, R., Proserpio, L. (2013), Diving too deep: how cognitive absorption and team learning behavior affect trainee learning, Academy of Management Learning $\mathcal{E}$ Education, Vol. 12/1, pp. 51-69.

Magni, M., Proserpio, L., Hoegl, M., Provera, B. (2009), Team-level antecedents of individual improvisation in information systems development projects, Research Policy, Vol. 33/8, pp. 1153-1165.

Maldonato, M. (2015), Quando decidiamo. Siamo attori consapevoli o macchine biologiche?, Firenze, Giunti.

Maldonato, M., Dell'Orco, S. (2017), Naturalistic Decision Making and intelligence of unconscious, in M. Squillante (a cura di), Decidere nella complessità, Roma, Edicampus edizioni, pp. 167-189.

Marano, L. (2010a), Aspetti sintattici dell'italiano parlato a Napoli. Un'analisi diagenerazionale, Tesi di Dottorato (XXIII ciclo - Tutor: Prof. Rosanna Sornicola), Dipartimento di Filologia Moderna, Università di Napoli "Federico II".

Marano, L. (2010b), Lingua e dialetto in due gruppi giovanili napoletani. Primi risultati di un'indagine in corso, in G. Marcato (a cura di), Tra Lingua e Dialetto, Atti del convegno internazionale di studi (Sappada/Plodn [Belluno] 25-30 giugno 2009), Padova, Unipress, pp. 73-78.

Marano, L. (2011), Il dialetto a Napoli: una riflessione su usi linguistici e valori funzionali, in G. Marcato (a cura di), Le nuove forme del dialetto, 
Atti del convegno internazionale di studi (Sappada/Plodn [Belluno] 25-30 giugno 2010), Padova, Unipress, pp. 123-128.

Marano, L. (in corso di stampa), Le dislocazioni a sinistra fra omogeneità formale flessibilità funzionale: uno studio sul parlato, Studi di grammatica italiana.

Margiotta, U. (2016), Una “buona scuola" potrà generare una "scuola dei talenti"?, Scienze e Ricerche, Vol. 23, pp. 15-17.

Marolda, L. (2017), Approccio al violino. Dalle corde vuote alla musica d'insieme, Napoli, Editoriale Scientifica.

Martiniello, L. (2012), Università. Verso nuovi modelli di management, Napoli, Guida.

Masud, M.A.H., Huang, X. (2012), An E-learning System Architecture Based on Cloud Computing, System, Vol. 10/ 11, pp. 74-78.

Maturi, P., Risolo, F.M. (2001), Il dialetto è un plus, Italiano E Oltre, Vol. 2, pp. 100-103.

Mazur, E. (1996), Peer Instruction: A User's Manual, Pearson.

McAuley, A., Stewart, B., Siemens, G., Cormier, D. (2010), The MOOC Model for Digital Practice. Reperibile on line all'indirizzo: http:// www.elearnspace.org/Articles/MOOC_Final.pdf.

McLean, C.L. (2005), Evaluating Critical Thinking Skills: Two Conceptualizations, Journal of Distance Education, Vol. 20/2, pp. 1-20.

McPeck, J.E. (1990), Teaching Critical Thinking, New York, Routledge.

McTighe, J., Wiggins, G., (2004), Fare progettazione: la "pratica" di un percorso didattico per la comprensione significativa, Roma, LAS.

Menzies, L.I. (1959), The Functions of Social Systems as a Defence Against Anxiety: A Report on a Study of the Nursing Service of a General Hospital, Human Relations, Vol. 13, pp. 95-121.

Mezirow, J. (1991), Transformative Dimension of Adult Learning, New York, John Wiley \& Sons [tr. it. (2003), Apprendimento e Trasformazione, Milano, Raffaello Cortina].

Merriam, S.B., Caffarella, R.S., Baumgartner, L.M. (2007), Lerning in Adulthood, San Francisco, John Wiley \& Sons.

Mikkelsen, L. (2005), Copular clauses. Specification, predication and equation, Amsterdam-Philadelphia, John Benjamins.

Mintzberg, E. (2011), Managing, San Francisco, Berrett-Koehler.

Mintzberg, E., Gosling, J. (2002), Educating Managers Beyond Borders, Academy of Management Learning E Education, Vol. 1/1, pp. 64-76.

Mintzberg, H. (1973), The nature of managerial work, New York, Harper \& Row. 
Mintzberg, H. (1976), Planning on the left side and managing on the right side, Harvard business review, Vol. 54/4.

Moore, J.L., Dickson-Deane, C., Galyen, K. (2011), E-Learning, Online Learning, and Distance Learning Environments: Are they the Same?, Internet and Higher Education, Vol. 14/2, pp. 129-135.

Morin, E. (1999), La tête bien faite, Paris, Seuil [tr. it. (2000), La testa ben fatta, Milano, Raffaello Cortina].

Morin, E. (2001), I sette saperi necessari all'educazione del futuro, Milano, Raffaello Cortina.

Muller Mirza, N. (2012), Interactions sociales et dispositifs de formation: Une perspective psychosociale, in V. Rivière (a cura di), Spécificités et diversités des interactions didactiques, Paris, Riveneuve, pp. 67-90.

Muller Mirza, N., Buty, C. (2015), L'argumentation dans les contexte de l'éducation: enjeux et questions vives, in N. Muller-Mirza e C. Buty (a cura di), L'argumentation dans les contextes de l'éducation, Bern, Lang.

Muller Mirza, N., Perret-Clermont, A.-N. (a cura di) (2009), Argumentation and education: Theoretical foundations and practices, New York, Springer.

Nappi, F. (2015), Didattica del diritto civile 2.0. Un prototipo di didattica fondata sull'addestramento al giudizio applicativo, Torino, Giappichelli.

Nash, J. (1951), Non-cooperative games, The Annals of mathematics, Vol. 54/2, pp. 286-295.

Nijkamp, P., Voogd, H. (1985), An informal Introduction to Multicriteria Evaluation, in G. Fandel e J. Spronk (a cura di), Multiple Criteria Decision Methods and Applications, Berlin-Heidelberg, Springer, pp. 61-84.

Nilsen, D., Campbell, D.P. (1993), Self-observer rating discrepancies: once an overrater always an overrater?, Human Resource Management, Vol. 32/2-3, pp. 265-281.

Nisbett, R.E., Ross, L. (1980), Human Inference. Strategies and Shortcomings of Social Judgement, Englewood Cliffs, Prentice-Hall [tr. it. (1989), L'inferenza umana. Strategie e lacune del giudizio sociale, Bologna, Il Mulino].

Niss, M. (2015), Mathematical competencies and PISA, in K. Stacey e R. Turner (a cura di), Assessing mathematical literacy, Heidelberg, New York, Dordrecht, Springer, chapter 2, pp. 35-56.

Nonnon, E. (2015), Préface, in N. Muller Mirza e C. Buty (a cura di), L'argumentation dans les contextes de l'éducation, Bern, Lang. 
OCDE (Organizzazione per la cooperazione e lo sviluppo economico) (1989), The Curriculum Redefined: Learning To Think - Thinking To Learn, Paris, OCDE.

OCDE (Organizzazione per la cooperazione e lo sviluppo economico) (1994), Redéfinir le curriculum: un enseignement pour le XXIème siècle, Paris, OCDE.

OCDE (Organizzazione per la cooperazione e lo sviluppo economico) (2003), Key Competencies for a Successful Life and a Well-Functioning Society, Paris, OCDE.

Ong, W.J. (1982), Orality and Literacy, London-New York, Methuen [tr. it. (1986), Oralità e scrittura, Bologna, Il Mulino].

Oproiu, G.C. (2015), A Study about Using E-learning Platform (Moodle) in University Teaching Process, Procedia-Social and Behavioral Sciences, Vol. 180, pp. 426-432.

Ozuru, Y., Briner, S., Kurby, C.A., McNamara, D.S. (2013), Comparing comprehension measured by multiple-choice and open-ended questions, Canadian Journal of Experimental Psychology, Vol. 67/3, pp. 215-277.

Padoa Schioppa, A. (1995), Il modello dell'insegnamento del diritto in Italia, Foro italiano, Vol. 120/5, pp. 413-419.

Parkes, M., Stein, S., Reading, C. (2015), Student preparedness for university e-learning environments, The Internet and Higher Education, Vol. 25, pp. 1-10.

Paul, R.W. (1984), Critical Thinking: Fundamental to Education for a Free Society, Educational Leadership, Vol. 42/1, pp. 4-14.

Pellerey, M. (2003), Le competenze individuali e il portfolio, Firenze, La Nuova Italia.

Pellerey, M. (2010), Competenze, conoscenze, abilità, atteggiamenti, Napoli, Tecnodid.

Peltier, J.W., Hay, A., Drago, W. (2005), The reflective learning continuum: reflecting on reflection, Journal of Marketing Education, Vol. 27/3, pp. 260-276.

Perini, M. (2007), L'organizzazione nascosta. Dinamiche inconsce e zone d'ombra nelle moderne organizzazioni, Milano, FrancoAngeli.

Perlingieri, P. (1989), Scuole tendenze e metodi. Problemi del diritto civile, Napoli, Edizioni scientifiche italiane.

Perret-Clermont, A.-N. (2004), The thinking spaces of the young, in A.-N. Perret-Clermont, C. Pontecorvo, L. Resnick, T. Zittoun e B. Burge (a cura di), Joining Society: Social Interactions and Learning in Adolescence and Youth, New York, Cambridge University Press, pp. 3-10. 
Perret-Clermont, A.-N. (2015), The architecture of social relationships and thinking spaces for growth, in C. Psaltis, A. Gillespie e A.-N. Perret-Clermont (a cura di), Social Relations in Human and Societal Development, Basingstokes, Palgrave Macmillan, pp. 51-70.

Perret-Clermont, A.-N., Perret, J.-F., Bell, N. (1991), The social construction of meaning, in L.B. Resnick, J.-M. Levine e S.D. Teasley (a cura di), Perspectives on Socially Shared Cognition, Washington, American Psychological Association, pp. 41-62.

Piaget, J. (1923), Le Langage et la pensée chez l'enfant, Neuchâtel-Paris, Delachaux et Niestlé [tr. it. (1955), Il linguaggio e il pensiero del fanciullo, Firenze, Editrice Universitaria].

Piaget, J. (2011), Psicologia dell'intelligenza, Firenze, Giunti.

Piro, F. (2015), Manuale di educazione al pensiero critico. Comprendere e argomentare, Napoli, Editoriale scientifica.

Polanyi, M. (1958), Personal Knowledge: Towards a Post-Critical Philosophy, Chicago, University of Chicago Press.

Pourtois, J.P. (1984), La ricerca-azione in pedagogia, in E. Becchi e B. Vertecchi (a cura di), Manuale critico della sperimentazione e della ricerca educativa, Milano, FrancoAngeli.

Proserpio, L. (2011), Comportamenti digitali. Essere giovani ed essere vecchi ai tempi di Internet, Milano, Egea.

Proserpio, L. (2016), Università, Apprendimento e Tecnologie, Prospettive in Organizzazione.

Proserpio, L., Gioia, D.A. (2007), Teaching the virtual generation, Academy of Management Learning and Education, Vol. 6/1, pp. 69-80.

Pugliatti, S. (1978), La giurisprudenza come scienza pratica, in Grammatica e diritto, Milano, Giuffrè.

Rao, R.V. (2007), Decision Making in the Manufacturing Environment, Introduction to Multiple Attribute Decision-making (MADM) Methods, London, Springer, pp. 27-41.

Rigotti E., Greco, S. (2010), Comparing the Argumentum Model of Topics to Other Contemporary Approaches to Argument Schemes: The Procedural and Material Components, Argumentation, Vol. 24/4, pp. 489-512.

Riahi, G. (2015), E-learning Systems Based on Cloud Computing: A Review, Procedia Computer Science, Vol. 62, pp. 352-359.

Rimiene, V. (2002), Assessing and developing students' critical thinking, Psychology Learning and Teaching, Vol. 2/1, pp. 17-22.

Risolo, F.M. (2001), Forme e archetipi dell'immaginario nella produzione 
scritta di allievi del biennio, in E. Piemontese (a cura di), I bisogni linguistici delle nuove generazioni, Firenze, La Nuova Italia, pp. 209-227. Rivoltella, P.C. (2005), Media Education. Fondamenti didattici e prospettive di ricerca, Brescia, Editrice La Scuola.

Rivoltella, P.C. (2006), Screen Generation. Gli adolescenti e le prospettive dell'educazione nell'età dei media digitali, Milano, Vita e Pensiero.

Robbins, S.P., Hunsaker, P.L. (2009), Training in Interpersonal Skills: TIPS for Managing People at Work, Upper Saddle River, Pearson Prentice Hall.

Roberts, J. (2006), L'impresa moderna, Bologna, Il Mulino.

Rodotà, S. (2015), Il diritto di avere diritti, Roma-Bari, Laterza.

Roehl, A., Reddy, S.L., Shannon, G.J. (2013), The flipped classroom: An opportunity to engage millennial students through active learning, Journal of Family and Consumer Sciences, Vol. 105/2, pp. 44-49.

Ronan, K.R., Johnston, D.M. (2005), Promoting community resilience in disasters: The role for schools, youth, and families, New York, Springer.

Roncayolo, M. (1978), Città, in R. Ruggiero (sotto la direzione di), Enciclopedia, Vol. III, Torino, Einaudi, pp. 3-84.

Saadé, R.G., Morin, D., Thomas, J.D. (2012), Critical thinking in E-learning environments, Computers in Human Behavior, Vol. 28/5, pp. 1608-1617.

Saaty, T.L. (1980), The Analytic Hierarchy Process, New York, McGraw-Hill.

Saaty, T.L. (1990), How to make a decision: the analytic hierarchy process, European journal of operational research, Vol. 48/1, pp. 9-26.

Saaty, T.L. (2001), Theory and Applications of the Analytic Network Process: Decision Making with Benefits, Opportunities, Costs, and Risks, Pittsburgh, Springer.

Saaty, T.L. (2008), Decision Making With The Analytic Hierarchy Process, International Journal Services Sciences, Vol. 1/1, pp. 83-98.

Sabatini, F. (1985), L'italiano dell'uso medio: una realtà tra le varietà linguistiche italiane, in G. Holtus e E. Radtke (a cura di), Gesprochenes Italienisch in Geschichte und Gegenwart, Tübingen, Gunter Narr Verlag, pp. 154-184.

Salvi, G. (1991), Le frasi copulative, in L. Renzi, G. Salvi e A. Cardinaletti (a cura di), Grande grammatica italiana di consultazione, vol. 2: I sintagmi verbale, aggettivale, avverbiale. La subordinazione, Bologna, Il Mulino, pp. 163-189.

Sangrà, A., Vlachopoulos, D., Cabrera, N. (2012), Building an Inclusive Definition of E-learning: An Approach to the Conceptual Framework, The International Review of Research in Open and Distributed Learning, Vol. 13/2, pp. 145-159. 
Santi, M., Oliverio, S. (a cura di) (2012), Educating for Complex Thinking through Philosophical Inquiry. Models, Advances, and Proposals for the New Millenium, Napoli, Liguori.

Saussure, F. (de) (1916), Cours de linguistique générale, a cura di C. Bally, A. Riedlinger e A. Sechehaye, Losanna-Parigi, Payot [tr. it. (2009), Corso di linguistica generale, a cura di T. De Mauro, Roma-Bari, Laterza].

Saussure, F. (de) (1922), Cours de linguistique générale, Paris, Payot [tr. it. (1983), Corso di linguistica generale, a cura di T. De Mauro, Roma-Bari, Laterza].

Scaglioni, R. (2008), Appunti di didattica delle discipline giuridiche privatistiche e pubblicistiche, Verona, Aemme.

Scalisi, V. (2012), Fonti, teoria, metodo. Alla ricerca della «regola giuridica» nell'epoca della postmodernità, Milano, Giuffrè.

Schein, E.H. (1987a), Process consultation, Reading, Addison-Wesley [tr. it. (1992), Lezioni di consulenza, Milano, Raffaello Cortina].

Schein, E.H. (1987b), The clinical perspective in fieldwork, London, Sage [tr. it. (1989), Sviluppo organizzativo e metodo clinico, Milano, Guerini e Associati].

Schön, D.A. (1999), Il professionista riflessivo. Per una nuova epistemologia della pratica professionale, Bari, Dedalo [ed. orig. (1983), The Reflective Practitioner: How Professionals Think in Action, New York, Basic Books].

Schubauer-Leoni, M.L. (1986), Maître-élève-savoir: analyse psychosociale du jeu et des enjeux de la relation didactique, Ph.D. Thesis, Faculty of Psychology and Educational Sciences, University of Geneva.

Schunk, D.H., Ertmer, P.A. (1999), Self-regulatory processes during computer skill acquisition: Goal and self-evaluative influences, Journal of Educational Psychology, Vol. 91/2, pp. 251-260.

Schmidt, H.G., Moust, J.H.C. (1999), A taxonomy of problems used in problem-based curricula, in Merrienboer (van), J., Moerkeke (van), G., Instructional design for problem-based learning: proceedings of the third workshop of the EARLI SIG instructional design, Maastricht, Datawyse, pp. 3-12.

Scriven, M., Paul, R. (2007), Defining critical thinking. The Critical Thinking Community, Foundation for Critical Thinking. Reperibile online all'indirizzo: http://www.criticalthinking.org/pages/defining-critical-thinking/766.

Searle, J.R. (1973), Austin on locutionary and illocutionary acts, in I. Berlin et al., Essays on J.L. Austin, Oxford, Clarendon Press, pp. 141-159. 
Searle, J.R. (1975a), A taxonomy of illocutionary acts, in K. Gunderson (a cura di), Language, Mind and Knowledge, Minneapolis, University of Minnesota Press, ora in Searle, J.R (1979), Expression and Meaning: Studies in the Theory of Speech Act, Cambridge, Cambridge University Press, pp. 1-29 [tr. it. (1989), Linguaggio, ragione, interazione. Per una teoria pragmatica degli atti linguistici, a cura di M. Sbisà, Bologna, Il Mulino, pp. 168-198].

Searle, J.R. (1975b), Indirect speech acts, in P. Cole e J.L. Morgan (a cura di), Syntax and Semantics III: Speech Acts, New York, Academic Press, ora in Searle, J.R (1979), Expression and Meaning: Studies in the Theory of Speech Act, Cambridge, Cambridge University Press, pp. 1-29 [tr. it. (1989), Linguaggio, ragione, interazione. Per una teoria pragmatica degli atti linguistici, a cura di M. Sbisà, Bologna, Il Mulino, pp. 252-280].

Sen, A. (2017), Welfare, in Collective Choice and Social Welfare, Cambridge, Harvard University Press.

Serianni, L. (2006), Grammatica Italiana, Torino, Utet.

Serianni, L. (2015), Scuola per cittadini, Il Sole 24 Ore, 8 marzo 2015.

Sfard, A. (2011), There is more to discourse than meets the ears: looking at thinking as communicating to learn more about mathematical learning, Educational Studies in Mathematics, Vol. 46, pp. 13-57.

Shaw, G.B. (1918), Androcles and the Lion: Overruled: Pygmalion, New York, Brentano.

Shor, I. (1993), Education is Politics, in P. McLaren e P. Leonard (a cura di), Paulo Freire: a critical encounter, New York, Rutgers.

Sicca, L.M. (2000), Chamber Music and Organization Theory: Some Typical Organizational Phenomena Seen Under The Microscope, Culture and Organization, Vol. 6/2, pp. 145-169.

Sicca, L.M. (a cura di) (2010), Leggere e scrivere organizzazioni. Estetica, umanesimo e conoscenze manageriali, Napoli, Editoriale Scientifica.

Sicca, L.M. (2013)1' , O l'impresa, o la vita. Storie organizzative ed epiche, Milano, Egea.

Sicca, L.M. (2015), Introduzione in Piro, F., Manuale di educazione al pensiero critico. Comprendere e argomentare, Napoli, Editoriale Scientifica.

Sicca, L.M. (2016), Diversity management, Inclusione, Analisi organizzativa. Spunti, punti e appunti, prospettive in organizzazione, Vol. 4.

Sicca, L.M. (2018)3), O l'impresa, o la vita. Storie organizzative ed epiche, Milano, Egea. 
Siegel, H. (1988), Educating reason: Rationality, Critical Thinking and Education, New York, Routledge.

Simkova, M., Tomaskova, H., Nemcova, Z. (2012), Mobile education in tools, Procedia-Social and Behavioral Sciences, Vol. 47, pp. 10-13.

Simon, H.A. (1955), A behavioral model of rational choice, The quarterly journal of economics, Vol. 69/1, pp. 99-118.

Simon, H.A. (1959), Theories of decision-making in economics and behavioral science, The American economic review, Vol. 49/3, pp. 253-283.

Simon, H.A. (1991), Bounded Rationality and Organizational Learning, Organization Science, Vol. 2/1, pp. 125-134.

Sinclair, J., Boyatt, R., Rocks, C., Joy, M. (2015), Massive Open Online Courses: A Review of Usage and Evaluation, International Journal of Learning Technology, Vol. 10/1, pp. 1-23.

Sitzmann, T., Ely, K., Brown, K., Bauer, K.N. (2010), Self-Assessment of Knowledge: A Cognitive Learning or Affective Measure?, Academy of Management Learning and Education, Vol. 9/2, pp. 169-191.

Sitzmann, T., Kraiger, K., Stewart, D., Wisher, R. (2006), The comparative effectiveness of Web-based and classroom instruction: A meta-analysis, Personnel Psychology, Vol. 59/3, pp. 623-664.

Sornicola, R. (1981), Sul parlato, Bologna, Il Mulino.

Sornicola, R. (2006)2, Topic and Comment, in K. Brown (a cura di), Encyclopedia of Language and Linguistics, vol. XII, Oxford, Elsevier, pp. 766-773.

Squillante, M. (a cura di) (2017), Decidere nella complessità, Roma, Edicampus edizioni.

Squillante, M., Fredella, M.I., Olivieri, M.G., Vitale, G. (2016), The Logic of Probability, a trip through uncertainty, Science and Philosophy, Vol. 4/2, pp. 3-18.

Squillante, M., Squillante, M., Violano, A. (a cura di) (2012), Sant'Agata de' Goti: tracce. Dai testi e dalle epigrafi verso un sistema informativo territoriale, Milano, FrancoAngeli.

Starkey, K., Tempest, S. (2010), Come uscire dalla crisi delle Business School, in L.M. Sicca (a cura di), Leggere e scrivere organizzazioni. Estetica, umanesimo e conoscenze manageriali, Napoli, Editoriale Scientifica.

Steed, A. (2012), The flipped classroom, Teaching Business \& Economics, Vol. 16/3, pp. 9-11.

Striano, M. (2001), La "razionalità riflessiva" nell'agire educativo, Napoli, Liguori. 
Striano, M. (2015), Per una teoria educativa dell'indagine. Riflessioni pedagogiche sulla logica di John Dewey, Lecce, Pensa Multimedia.

Supiano, B. (2013), Employers want broadly educated new hires, survey finds, The Chronicle of Higher Education, April 10, 2013. Reperibile online all'indirizzo: http://chronicle.com/article/Employers-Want Broadly/138453/.

Swan, K. (2001), Virtual interaction: Design factors affecting student satisfaction and perceived learning in asynchronous online courses, Distance Education, Vol. 22/2, pp. 306-331.

Tessaro, F. (2014), Compiti autentici o prove di realtà? Authentic tasks or reality tests?, Formazione $\mathcal{E}$ Insegnamento, Vol. 12/3, pp. 77-88.

Thomson, A. (2002), Critical reasoning. A Practical introduction, London-New York, Routledge [tr. it. (2009), Argomentare e imparare a farlo meglio, Milano, Mimesis].

Traverso, V. (1990), L'analyse des conversations, Paris, Nathan.

Triantaphyllou, E. (2000), Multi-Criteria Decision Making Methods, Multi-criteria Decision Making Methods: A Comparative Study. Applied Optimization, Vol. 44, pp. 5-21.

Vannini, I. (2010), La qualità nella didattica. Metodologia e strumenti di progettazione e valutazione, Trento, Centro Studi Erickson.

Varchetta, G. (1990), Sviluppo organizzativo e sviluppo culturale nella gestione delle risorse umane, in D. Boldizzoni (a cura di), Nuovi paradigmi per la direzione del personale, Torino, Isedi.

Vaughn, L. (2005), The Power of Critical Thinking. Effective Reasoning about Ordinary and Extraordinary Claims, Oxford, Oxford University Press.

Vega, G. (2013), The case writing workbook, Armonk, M.E. Sharpe.

Venkatesh, V., Davis, F.D. (2000), A theoretical extension of the technology acceptance model: Four longitudinal field studies, Management Science, Vol. 46/2, pp. 186-204.

Ventre, A.G.S. (2018), Matematica. Metodi per il Calcolo e la Rappresentazione, Roma, Aracne.

Ventre, A.G.S, Ventre, V. (2012), La decisione. Comportamenti e scelte razionali dell'individuo, Napoli, Liguori.

Vergnaud, G. (2015), Argumentation et conceptualisation: commentaires, in N. Muller Mirza e C. Buty (a cura di), L'argumentation dans les contextes de l'éducation, Bern, Lang, pp. 383-392.

Viceconte, E. (2017), Le decisioni strategiche nell'impresa, in M. Squillante (a cura di), Decidere nella complessità, Roma, Edicampus edizioni, pp. 97-145. 
Vygotsky, L.S. (1962), Thought and language, Cambridge, MIT Press.

Vygotsky, L.S. (1978), Mind in society: The development of higher psychological processes, a cura di M. Cole, V. John-Steiner, S. Scribner e E. Souberman, Cambridge-London, Harvard University Press.

Walton, D., Krabbe, E.C.W. (1995), Commitment in Dialogue. Basic concepts of interpersonal reasoning, New York, State University of New York Press.

Watzlawick, P. (1984), The invented reality, New York, W.W. Norton and Company [tr. it. (1989), La realtà inventata, Milano, Feltrinelli].

Watzlawick, P. (1986), Vom Schlechten des Guten oder Hekates Lösungen, München, Piper [tr. it. (1987), Di bene in peggio. Istruzioni per un successo catastrofico, Milano, Feltrinelli].

Watzlawick, P. (1987), Anleitung zum ünglücklichsein, München, Piper [tr. it. (1997), Istruzioni per rendersi infelici, Milano, Feltrinelli].

Wegerif, R. (2013), Dialogic: Education for the Internet Age, London, Routledge.

Weick, K.E. (1977), Enactment Processes in Organizations, in B.M. Staw e G.R. Salancik (a cura di), New Directions in Organizational Behaviour, Chicago, St. Clair Press.

Weick, K.E. (1979), Cognitive Processes in Organizations, in B.M. Staw (a cura di), Research in Organizational Behaviour, Greenwich, JAI Press, vol. 1, pp. 41-74.

Wenger, E. (1998), Communities of practice: learning, meaning and identity, New York, Cambridge University Press [tr. it. (2006), Comunità di pratica. Apprendimento, significato e identità, Milano, Raffaello Cortina]. Wertsch, J.V. (1998), Mind as action, New York, Oxford University Press. Wiggins, G.P. (1998), Educative assessment. Designing Assessments to Inform and Improve Student Performance, San Francisco, Jossey-Bass Publishers.

Wiggins, G.P. (1999), Assessing student performance: exploring the purpose and limits of testing, San Francisco, Jossey-Bass Publishers.

Wiggins, G.P., McTighe, J. (2004), Fare progettazione: la "teoria" di un percorso didattico per la comprensione significativa, Roma, LAS.

Wiggins, G.P., McTighe, J. (2005)², Understanding by design, Alexandria, Association for Supervision and Curriculum Development ASCD. Wiggins, G.P. (2012), Seven keys to effective feedback, Educational Leadership, Vol. 70/1, pp. 10-16.

Wittemberg-Salzberger, I. (1983), Di fronte ad una nuova esperienza, Prospettive psicoanalitiche nel lavoro istituzionale, Vol. I, pp. 20-38. 
Woods, J., Irvine, A.D., Walton, D.N. (2004)², Argument: Critical Thinking, Logic and the Fallacies, Toronto, Pearson.

Yin, R.K. (2014) ${ }^{5}$, Case study research: Design and methods, London, Sage publications.

Yuan, L., Powell, S. (2013), MOOCs and disruptive innovation: Implications for higher education, In-depth, Vol. 33/2, pp. 1-7.

Zagrebelsky, G. (1997), Il diritto mite. Legge, diritti, giustizia, Torino, Einaudi.

Zan, S. (a cura di) (1988), Logiche di azione organizzativa, Bologna, Il Mulino.

Žegarac, V. (2006), Language, in K. Brown (a cura di), Encyclopedia of Language and Linguistics, vol. VII, Oxford, Elsevier, pp. 321-326. 


\section{Indice dei nomi}

Abrami, Philip C., 280

Adeola, Oladele S., 323

Al-Adwan, Amer, 326

Al-Fadhli, Salah, 323

Al-Qathani, Awadh A.Y., 323, 325, 327-328

Alberici, Aureliana, 45, 47, 241n.

Alberoni, Francesco, 134-138

Alfonzetti, Giovanna, 224

Allais, Maurice, 146

Alighieri, Dante, 207

Andersen, Espen, 296

Anderson, Terry, 324, 339

Angelelli, Rosanna, 181n.

Antonelli, Giuseppe, 212

Anvur, 43, 329

APA, 41

Arcidiacono, Francesco, 121-122

Argyris, Chris, 233n.

Ariosto, Ludovico, 217, 220

Aristotele, 89, 103-104

Arnsperger, Christian, 347

Arrow, Kenneth J., 153

Arum, Richard, 42

Ashby, Ross, 234n.

Atabaki, Ali Mohammad S., 323

Austin, John L., 123

Ausubel, David, 55-56
Bacci, Silvia, 149

Bacone, Francesco, 32

Baker, 121-123

Bakthin, Mikhail M., 126

Baldacci, Massimo, 61

Banerjee, Abhijit V., 327

Baricco, Alessandro, 73

Barnard, Chester, 237

Barrows, Howard S., 67

Barry, Jim, 328

Basile, Luciano, 154

Bateman, Roger, 325

Bateson, Gregory, 234n.

Bauman, Zygmunt, 54

Bayne, Siân, 328-339

Beaudoin, Michael, 339

Beckhard, Richard, 233n.

Beckmann, Jennifer, 323

Begg, Michael, 325

Belfagor, 220

Bell, Bradford S., 233n., 328

Bennis, Warren G., 233n.

Bereiter, Carl, 195

Berger, Peter L., 234 e n., 282

Berk, Ruper, 342

Berlyne, Daniel E., 62

Berruto, Gaetano, 206n., 210-

211, 220, 221n.

Bertagna, Giuseppe, 54 
Bertinetto, Pier Marco, 220n.

Bick, Esther, 236

Bion, Wilfred R., 236

Bizjak, Davide, 23

Boisvert, Jacques, 342

Bok, Derek, 328n.

Boncori, Ilaria, 328n.

Boswell, Amy, 279

Boutinet, Jean-Pierre, 45

Bowlby, John, 236

Boyd, Richard N., 231

Blanche-Benveniste, Claire, 216n.

Breton, Margot, 37

Bruner, Jerome, 188, 193

Buckingham, David, 54

Burbules, Nicholas C., 342

Burke, Werner W., 233n.

Burrell, Gibson, 234 e n.

Calvert, Dennis, 328

Cambi, Franco, 46, 68

Campbell, David P., 299

Camus, Albert, 143, 145

Canonico, Paolo, 23

Cantù, Paola, 85

Capobianco, Rosaria, 15, 21, $47,54,84$

Cappetta, Rossella, 299

Carrara, Francesco, 219

Carril, Pablo C.M., 323, 326

Castoldi, Mario, 50, 60-62

Castoriadis, Cornelius, 346-347

Cattani, Adelino, 85

Cavallo, Bice, 22, 156, 166-167

Chen, Kuan-Chou, 290

Chiandotto, 149

Chomsky, Noam, 178, 205

Chuang, Keh-Wen "Carin", 290

Cicerone, Marco Tullio, 223
Circe, $194 n$.

Clark, Heather, 324

CNIPA, 325

Cochrane, Thomas, 325

Cohen, Wesley M., 312

Comoglio, Mario, 61

Condorcet, Nicolas (de), 153

Consiglio, Stefano, 23

Coppola, Cristina, 139

Corbetta, Piergiorgio, 234n., 329

Corbi, Enricomaria, 362

Corno, Dario, 196

Cornoldi, 56

Cortelazzo, Manlio, 203

Coupland, Nikolas, 212

Creswell, John, 328

Cunliffe, Ann L., 283

Cyrulnik, Boris, 37

D'Achille, Paolo, 211n., 221n.

D'Apuzzo, Livia, 154, 156

Da Re, Franca, 62

Daniele, Nino, 362

Dante vedi Alighieri, Dante

Davies, Peter, 37

Davis, Fred D., 297, 306, 317

De Bono, Edward, 153

De Gregori, Francesco, 73

De Liso, Giovanni, 147

De Luca, Erri, 73

De Mauro, Tullio, 15, 22, 180 e

n., 181n., 183, 196n., 211, 323

De Morgan, Augustus, 95

De Nito, Ernesto, 23

Deakin Crick, Ruth, 45

Dell'Orco, Silvia, 147

Delors, Jacques, 38

Demetrio, Duccio, 241n. 
D’Errico, Francesco, 242, 363

Desay, 282

Deschacht, Nick, 339

de Vita, Paolo, 363

Dewey, John, 19, 28, 48-49, 6566, 87, 282

Di Nola, Antonio, 156

Di Rienzo, Paolo, 47

Doise, 121

Du Gay, Paul, 232

Dudley, Lola W., 283

Duflo, Esther, 327

Dunning, David, 299

Dwyer, James S., 279-280

Dyck, Loren R., 279

Eemeren (van), Frans H., 121123, 131

Eggers, Fabian, 279

Einstein, Albert, 146

Elder, Linda, 204 e n.

Elliott, Mark A., 279

Ennis, Robert, 30, 49, 52, 85, 274

Enrico IV (re), 107-108

Ertmer, Peggy A., 300

Eutifrone, 103

Ewan, Christine, 328

Facione, Nooren C., 43

Fattoruso, Gerarda, 22

Federman, Jessica E., 328

Foerster (von), Heinz, 234n.

Foucault, Michel, 91, 232, 367

Frabboni, Franco, 239

Frassica, Nino, 73

Fredella, Maria Incoronata, 22

French, Simon, 154

French, Wendell L., 233

Gagliardi, Pasquale, 232n.
Gambarelli, Gianfranco, 148

Gentile, Teresa A.R., 23

Gergen, Kenneth J., 234

Glaser, Barney G., 234, 280

Glasersfeld (von), Ernst, 234

Goeman, Katie, 339

Gosling, Jonathan, 293, 304-305

Gramsci, Antonio, 26

Greco, Salvatore, 121-122 e n.

Greco, Sara, 121-122 e n.

Gregorio VII (papa), 107-108

Grice, Paul H., 123, 127

Griffiths, Thomas L., 241

Grootendorst, Rob, 121-123

Grossen, 121

Guerriero, Anna R., 196n.

Hansen, David T., 33

Hautamäki, Jarkko, 46

Heilmann, Luigi, 213

Hendry, John, 361

Henry, 366

Higgins, Steven, 323, 325, 327-

328

Higgs, 282

Hilbert, David, 89

HLS, 296

Holmes, Bryn, 328

Huang, Xiaodi, 326

Hung, Woei, 67

Hunsaker, Phillip L., 296

Hurwitz, Adolf, 152

Hymes, Dell, 178, 205

Iannaccone, Antonio, 121-122,

126-127, 139

Ishizaka, Alessio, 163

Jain, Pooja, 327 
Jakobson, Roman, 209

Johnson-Laird, Philip N., 94

Johnston, David M., 37

Jonassen, David H., 67

Kahneman, Daniel, 90, 146, 240n.

Keleman, Ken S., 296

Kennedy, Robert, 119

Khalfan, Abdulwahed, 323

Knights, David, 232

Knowles, Malcom, 241, 293

Koch, Peter, 211

Kolb, David A., 242, 282, 288, 304

Krabbe, Erik C.W., 126-127

Kripke, Saul, 89

Kristiansen, Tore, 212

Krovetz, Martin L., 37

Kruger, Justin, 299

Kuhn, Thomas, 231

Kukulska-Hume, Agnes, 325

Kuli, 37

Kulig, Judith C., 37

Kurilovas, Eugenijus, 326

Lacan, Jacques, 346

Lage, Maureen J., 290

Lambrecht, Knud, 216n.

Land, Ray, 328, 339

Langdell, Cristopher C., 296

Laplace, Pierre Simon, 152

Ledgeway, Adam, 208n.

Lehman, Darrin R., 280

Leitao, Selma, 121

Lerner, Alan J., 178

Lettieri, Nicola, 147

Levi, Primo, 134-138

Levinthal, Daniel A., 312
Levy, Yair, 340

Lewis, Michael, 146

Ligorio, 121

Lin, Wen-Shan, 325

Lipman, Matthew, 21, 27-31, 34, 36

Lippmann, Walter, 117

Liu, Ou Lydia, 42

Lodi, Mario, 180n.

Loewe, Frederick, 178

Loiodice, Isabella, 69

Lops, Vito, 119

Lovelace, Kathi J., 279

Luckmann, Thomas, 234 e n.

Luhmann, Niklas, 66

Lyons, John, 218n., 225

Maanen (van), John, 228 e n., 236

Machiavelli, Niccolò, 221-222

MacKnight, Carol B., 213

Magni, Massimo, 282, 297, 299

Malaguti, Elena, 37

Maldonato, Mauro, 147, 363

Mallozzi, Chiara, 23

Malthus, Thomas R., 109-110

Mancini, Pasquale S., 21, 97

Manzoni, Alessandro, 217-218

Marano, Luca, 22, 211n., 215,

221n.-222n.

Margiotta, Umberto, 53

Marolda, Luigi, 23, 267

Marsilio, 220

Martiniello, Lucia, 341

Massimilla, Edoardo, 362

Masullo, Aldo, 362

Masud, Anwar Hossain, 326

Maturi, Pietro, 22, 191, 362, 364

Mayer, 324

Mazur, Eric, 256-257 
McAuley, Alexander, 326-327

McLean, Cheryl L., 323

McPeck, John, 86-87

McTighe, Jay, 55-58, 60-61, 64

Mead, Margaret, 234n.

Mele, Cristina, 362-363

Mengaldo, Pier Vicenzo, 207n.

Menone, 103

Menzies, Isabel E.P., 236-237

Mezirow, Jack, 241

Michelson, Albert A., 146

Mikkelsen, Line, 225n.

Mill, John S., 114

Mintzberg, Henry, 240, 293, 304-305

Mollo, Monica, 21

Montaigne (de), Michel, 18, 51

Montale, Eugenio, 190n.

Montessori, Maria, 283

Moore, Joi, 325

Morfeo, 367

Morgan, Gareth, 234 e n.

Morgenstern, Oskar, 151

Morin, Edgar, 18, 50-51, 185

Morley, Edward, 146

Moust, Jos H.C., 67

Mugny, 121

Muller Mirza, Nathalie, 126

Nash, John, 151

Nemery, Philippe, 163

Neumann (von), John, 151, 234n.

Nicodemi, Mario, 23, 255, 363

Nilsen, Dianne, 299

Nisbet, John, 37

Nisbett, Richard E., 89-90, 894, 280

Niss, Mogens, 129

Nunziante, Giulia, 118
OCSE, 239, 351 e n., 355n., 358

OECD, 37-38, 40

Olivieri, Maria Grazia, 22

Omero, 194

Oproiu, Gabriela C., 326-327

Orlando, 217, 220

Ozuru, Yasuhiro, 52

Palmieri, Anna, 363

Parigi, Silvia, 155 e n., 362

Parkes, Mitchell, 326

Parthenope, 169

Paul, Richard, 85, 204

Pederzoli, Giorgio, 148, 151

Peirce, Charles S., 28

Pellerey, Michele, 46, 239

Peltier, James W., 283

Penelope, 194n.

Perelman, Chaïm, 85

Perini, Mario, 236

Perret-Clermont, Anne-Nelly,

121-122, 126-128

Petitti, Maria Rita, 21, 84

Petrarca, Francesco, 219

Piaget, Jean, 154

Piovani, Pietro, 362

Piro, Francesco, 21, 93, 121, 122n., 202n., 231, 280, 324, 361n., 362-364

Plantin, 122

Platone, 103-104, 344, 367

Plinio il Vecchio, 22

Polany, Michael, 283

Polifemo, 194n.

Pourtois, Jean-Pierre, 354

Powell, Stephen, 327-328

Proserpio, Luigi, 23, 279, 286, 292, 297, 314

Purswani, Geetanjali, 327 
Pygmalion, 178

Rabelais, François, 134-136

Rahi, 326

Raimondi, Ezio, 217

Ramim, Michelle M., 340

Rao, Ravipudi Venkata, 163

Recinto, Giuseppe, 23

Riesz, Frigyes, 156

Rigotti, Eddo, 121-122 e n.

Rimiene, Vaiva, 280

Risolo, Fabio M., 15, 22, 191, 194

Rivoltella, Cesare P., 54

Robbins, Stephen P., 296

Roberts, John, 331, 334

Roehl, Amy, 289

Roksa, Josipa, 42

Ronan, Kevin, 37

Roncayolo, Marcel, 207n.

Ross, Lee D., 89-90, 94, 234n.

Russell, Bertrand, 89

Saadé, Raafat G., 323

Saaty, Thomas L., 146, 157, 159

Sabatini, Francesco, 220, 224

Salaman, Graeme, 232

Salas, 283

Salvi, Giampaolo, 216n., 225n.

Sangrà, Albert, 325

Saussure, Ferdinand (de), 177, 205n., 207n.

Scardamalia, Marlene, 195

Schein, Edgar H., 233n.

Schiano, Bill, 296

Schön, Donald A., 66

Schorr, Eberhard K.,66

Schunk, Dale H., 300

Schwarz, 121, 123

Schmidt, Henk G., 67
Scriven, Michael, 204

Searle, John R., 123

Sen, Amartya, 114, 153

Seneca, Tullio Anneo, 219

Sennert, Daniel, 20

Serianni, Luca, 218n., 254

Sfard, Anna, 126

Shannon, Claude, 234n.

Shaw, George B., 178 e n.

Sheffler, 280

Shor, Ira, 343, 346

Sicca, Luigi M., 23-24, 231 e n., 233, 237, 261, 281, 361-364

Siegel, Harvey, 85n.

Simkova, Monika, 325

Simon, Herbert, 240, 284, 320

Sinclair, Jane, 326

Sitzmann, Traci, 286, 300, 306, 311

Smith, Vernon, 240n.

Socrate, 103, 200

Sornicola, Rosanna, 216n., 219

Speck, Richard F., 119

Spinoza, Baruch, 87

Squillante, Massimo, 22, 145,

154, 157, 363-364

Starkey, Ken, 325

Steed, Anthony, 289

Strauss, Anselm L., 234

Striano, Maura, 21, 84, 362, 364

Supiano, Beckie, 282

Swan, Karen, 308

Tamblyn, Robyn M., 67

Tarski, Alfred, 89

Telemaco, 194n.

Tempest, Sue, 325

Tessaro, Fiorino, 61

Testa, Italo, 85 
Thaler, Richard, 146n.

Thomson, Anne, 202n.

Tortora, Daniela, 363

Toulmin, Stephen, 85

Travaglione, Antonia, 22

Traxler, John, 325

Triantaphyllou, Evangelos, 160

Tverski, Amos, 146

Ulisse, $194 \mathrm{n}$.

Unesco, 37-38, 84

Unhcr, 73

Valerio, Paolo, 363

Vannini, Ira, 64

Varchetta, Giuseppe, 233n.

Vaughn, Lewis, 85

Vega, Gina, 296

Venkatesh, Viswanath, 297, 306

Ventre, Aldo G.S., 166

Viceconte, Enrico, 147

Villani, Natascia, 24
Vygotskij, Lev S., 121, 124-125

Wald, Abraham, 152

Walton, Douglas, 126-127

Wang, Chun-Hsien, 325

Watzlawick, Paul, 234 e n.

Weber, Peter, 323

Weick, Karl E., 234 e n.

Whitman, Charles, 119

Wiggins, Grant, 55-58, 60-61,

64

Willmott, Hugh, 232

Wittemberg-Salzberger, Isca, 237

Woods, John, 86

Yin, Robert K., 331

Yuan, Li, 327-328

Zan, Stefano, 232n.

Žegarac, Vladimir, 205n.

Zenone, 89

Zolli, Paolo, 203 


\section{Hanno scritto nella Collana punto org}

www.puntoorg.net

1. L.M. Sicca (a cura di)', Leggere e scrivere organizzazioni. Estetica, umanesimo e conoscenze manageriali (con postfazione di F. Piro), 2010.

2. L.M. Sicca, Alla fonte dei saperi manageriali. Il ruolo della musica nella ricerca per l'innovazione e per la formazione delle risorse umane, 2012.

3. A. Di Scipio, Pensare le tecnologie del suono e della musica (con prefazione di R. Diana), 2012.

4. R. Musto, Scienza Natura Cambiamento (con prefazione di M. Nicodemi), 2012.

5. R. Musto, L'assoluto e le cose (con prefazione di C. Albarella e postfazione di G. Imbruglia), 2013.

6. Aa.Vv. ", I linguaggi dell'organizzare. Musica e testo tra dono e disinteresse, 2013.

7. B. Masiello, Fiducia nelle reti. Strategie per la crescita nei mercati internazionali delle PMI (con prefazione di F. Izzo), 2013.

8. Aa.Vv."II, Tavola rotonda. Umanesimo del management attraverso gli occhi dell'altro, 2013.

9. M. Calcagno, Narrare terre di mezzo. Management arte design (con prefazione di S. Faccipieri e postfazione di A. Comacchio), 2013.

10. R. Diana, Disappartenenza dell'Io (con prefazione di L.M. Sicca), 2014.

${ }^{1}$ Con scritti di Per Olof Berg e Kristian Kreiner, Robert W. Witkin, Barbara Czarniawska e Carl Rhodes, Ken Starkey e Sue Tempest, John Hendry, Karin Knorr Cetina.

"Con scritti di Luigi Maria Sicca, Umberto di Porzio, Rosario Diana, Agostino Di Scipio, Mariella De Simone, Bernardo Maria Sannino, Chiara Mallozzi, Lorenzo Pone, Giancarlo Turaccio.

"I Con scritti di Luigi Maria Sicca, Francesco Izzo, Maura Striano, Giulia Dell'Aquila, Felice Casucci, Francesco Perillo, Rosario Diana, Paola Giampaolo, Davide Bizjak, Gilberto-Antonio Marselli, Franco Vitelli, Maria Rosaria Napolitano. 
11. Aa.Vv. ${ }^{\text {IV }}$, Sergio Piro. Maestri e allievi, 2014.

12. F.D. Perillo (a cura di) ${ }^{\mathrm{v}}$, Impresa imperfetta, 2014.

13. L.M. Sicca e L. Zan (a cura di) ${ }^{\mathrm{vi}}$, Management Arti Culture. Resoconto del primo anno del GSA - Accademia Italiana di Economia Aziendale, 2014.

14. M. Iaccarino, Un mondo assetato. Come il bisogno di acqua plasma la civiltà (con prefazione di F.P. Casavola e postfazione di A. Giannola), 2015.

15. F. Piro, Manuale di educazione al pensiero critico. Comprendere e argomentare (con prefazione di T. De Mauro), 2015.

16. F. D'Errico, Fuor di metafora. Sette osservazioni sull'improvvisazione (con prefazione di P. de Vita e postfazione di M. Maldonato), 2015.

17. E. Mollona, Computer Simulation in Social Sciences. A logic of enquiry (with a foreword by G. Colombo and an afterword by D. Secchi), 2015.

18. S. Oliverio, L.M. Sicca, P. Valerio ${ }^{\mathrm{VI}}$, Transformare le pratiche nelle organizzazioni di lavoro e di pensiero (con prefazione di G. Manfredi), 2015.

19. P. Valerio, C. Bertolazzi e P. Marcasciano (a cura di) ${ }^{\mathrm{v} u}$, Transformare l'organizzazione dei luoghi di detenzione. Persone transgender e gender non conforming tra diritti e identità (con prefazione di L.M. Sicca e postfazione di A. Hochdorn), 2016.

rv Con scritti di Giuseppe Cantillo, Tullio De Mauro, Aldo Masullo, Mariapaola Fimiani, Teresa Capacchione, Antonio Mancini, Roberto Beneduce, Enrico De Notaris, Fulvio Marone, Dario Stefano Dell'aquila, Luigi Maria Sicca, Francesco Piro.

v Con scritti di Pier Luigi Celli, Eugenio Mazzarella, Enzo Rullani, Luigi Maria Sicca, Francesco Varanini.

vi Con scritti di Stefano Baia Curioni, Paola Dubini e Ludovica Leone, Sara Bonini Baraldi e Luca Zan, Monica Calcagno e Luigi M. Sicca, Donata Collodi, Francesco Crisci e Andrea Moretti, Roberto Ferrari e Alessandro Hinna, Francesco Giaccari, Francesca Imperiale e Valentina Terlizzi, Daniele Goldoni, Pamela Palmi.

vі Con scritti di Anna Lisa Amodeo, Christian Ballarin, Davide Bizjak, Ilaria Boncori e Paolo Fazzari, Rossella Bonito Oliva, Simone Cangelosi, Marco De Giorgi, Guglielmo Faldetta, Vittoria Fiorelli, Stefano Maltese, Porpora Marcasciano, Piergiorgio Masi, Antonia Monopoli e Chiara Repetto, Andrea Morniroli, Edoardo Mollona, Cristiano Scandurra, Luca Solari, Maria Spanò, Maria Gigliola Toniollo.

viI Con scritti di: Luigi Maria Sicca, Paolo Valerio, Carmen Bertolazzi, Alexander Hochdorn, Porpora Marcasciano, Luca Chianura, Damiana Massara, Daniela A. Nadalin, Adriana Godano, Elia De Caro, Tito Flagella, Anna Lorenzetti, Giuseppe Ferraro, Caterina Peroni, Vittoria Colonna, Vicente de Paula Faleiros. 
20. M.R. Napolitano e V. Marino (a cura di) ${ }^{\mathrm{Ix}}$, Cultural Heritage e Made In Italy. Casi ed Esperienze di Marketing Internazionale (con prefazione di G. Volpe e postfazione di A. Mattiacci), 2016.

21. M. Lusiani, Discourses of Planning (with a preface by L. Zan and an afterword by A. Langley), 2016.

22. F.D. Perillo, Simposio manageriale (con prefazione di A. Masullo e postfazione di P.L. Celli), 2016.

23. P. Ferri, I commissariamenti nel settore culturale italiano. Obiettivi, azioni, risultati (con prefazione di L. Zan e postfazione di G. Grossi), 2016.

24. L. Pareschi, Controcampo letterario. Strategie di intermediazione e accesso all'industria editoriale (con prefazione di P. Dubini e postfazione di G. Colombo), 2016.

25. G.-A. Marselli, Mondo contadino e azione meridionalista. L'esperienza del gruppo rossi-doria a portici (con prefazione di E. Mazzetti e postfazione di F. Vitelli), 2016.

26. F. Accardix, Risk and Control Governance. A value-creation perspective (with a preface by A. De Nicola; an introduction by V. Atella and an afterword by S. Bozzolan), 2017.

27. I. Boncori (ed.) ${ }^{\mathrm{x}}, L G B T+$ Perspectives - The University of Essex Reader, (with a foreword by A. Forster), 2017.

28. A. Papa, “... Una cappella cavata dentro il monte...". Storia minima del complesso monastico di S. Lucia al Monte (con prefazione di L. D'Alessandro), 2017.

זx Con scritti di Loretta Battaglia, Giuseppe Bertoli, Roberta Biandolino, Michelle Bonera, Enrico Bonetti, Mauro Cavallone, Elena Cedrola, Marta Cerquetti, Maria Chiarvesio, Anna Codini, Emanuela Conti, Eleonora Di Maria, Barbara Francioni, Antonella Garofano, Francesco Izzo, Giulia Lanzilli, Gaetano Macario, Giulio Maggiore, Francesca Magno, Vittoria Marino, Barbara Masiello, Michela Matarazzo, Alberto Mattiacci, Marta Maria Montella, Fabio Musso, Maria Rosaria Napolitano, Alessandro Pagano, Tonino Pencarelli, Giovanna Pegan, Michele Quintano, Riccardo Resciniti, Marcello Risitano, Angelo Riviezzo, Savino Santovito, Elisabetta Savelli, Michele Simoni, Annarita Sorrentino, Raffaella Tabacco, Donata Vianelli.

${ }^{x}$ Con scritti di Roberto Rosato, Nicoletta Mincato, Carlo Nicoletti, Paolo De Paolis, Alessandro Salibra Bove.

хг Con scritti di Alison J. Taylor-Lamb, Jamie Raines, Thomas Currid and Carl Chandra, Martin Harrison and Peter Martin, Rainer Shulze, Fleur Jeans and Teresa Eade, Tuesday Wats, Amy Anderson, Sco Lawley. 
29. R. Diana, L.M. Sicca e G. Turaccio ${ }^{\mathrm{xI}}$, Risonanze. Organizzazione, musica, scienze (con prefazione di A. Strati e postfazione di A. Solbiati), 2017.

30. F. D'Errico, Armonia funzionale e modalità. Rudimenti per l'improvvisazione a indirizzo jazzistico (con introduzione di F. Piro e prefazione di R. Grisley), 2017.

31. M. Calcagno, Interpreting Innovation. Design Creativity Art (con introduzione di F. Izzo; prefazione di A. Moretti e postfazione di J. Metelmann), 2017.

32. G. Balirano, Gardai \& Badfellas: The Discursive Construction of Organised Crime in the Irish Media, 2017.

33. M.C. Mason e A. Moretti, Tattoo Management. Mercati, attori, valore, 2017.

34. P. Testa, Innovazione del modello di business. Le dimensioni latenti nella letteratura di management (con prefazione di L. Cantone), 2017.

35. L. Massa, Viva 'o re! Municipio e dintorni (con introduzione di L.M. Sicca; prefazione di E. Borgonovi e postfazione di C. Mochi Sismondi), 2017.

36. F. Pavan, Memini. Piccole storie di storia della musica (con introduzione di E. Mazzarella; prefazione di R. Alessandrini e postfazione di V. Moroni), 2017.

37. C. Mallozzi e D. Tortora ${ }^{\mathrm{x} I I}$, La bottega del suono. Mario Bertoncini. Maestri e allievi (con prefazione di M. Nicodemi e postfazione di L.M. Sicca), 2017.

38. G. Melis, Collaborazione e apprendimento nei processi di co-creazione di valore. Il caso delle destinazioni turistiche (con prefazione di M.R. Napolitano e postfazione di B. Argiolas), 2018.

39. G. Viglia e A.C. Invernizzi, Il ruolo dell'hubris nella gestione imprenditoriale (con prefazione di C. Mauri), 2018.

xII Con scritti di Davide Bizjak, Dario Casillo, Rosario Diana, Umberto Di Porzio, Agostino Di Scipio, Chiara Mallozzi, Mario Nicodemi, Lorenzo Pone, Rosalba Quindici, Sonia Ritondale, Tommaso Rossi, Bernardo Maria Sannino, Luigi Maria Sicca, Cristian Sommaiuolo, Giancarlo Turaccio, Paolo Valerio.

xuI Con scritti di Mario Bertoncini, Davide Bizjak, Gianmario Borio, Pietro Cavallotti, Andrew Culver, Francesco D'Errico, Charles de Mestral, Michelangelo Lupone, Chiara Mallozzi, Alessandro Mastropietro, Mario Nicodemi, Luigino Pizzaleo, Lorenzo Pone, Ingrid Pustijanac, John Rea, Bernardo Maria Sannino, Luigi Maria Sicca, Daniela Tortora. 
40. T. Russo Spena e C. Mele, Practising innovation: a socio-material view (with a preface by J. Spohrer), 2018.

41. I. Boncori, Race, Ethnicity and Inclusion. The University of Essex Reader (with a foreword by A. Forster and a postface by M. Śliwa), 2018.

42. K.E. Russo, The Evaluation of Risk in Institutional and Newspaper Discourse: The Case of Climate Change and Migration (with a preface by G. Bettini), 2018.

43. R. Pera, When consumers get creative. Cocreation in the individual and collective realm (with a preface by D. Dalli), 2018. 